\title{
Structural Requirement of TAG-1 for Retinal Ganglion Cell Axons and Myelin in the Mouse Optic Nerve
}

\author{
Elli Chatzopoulou, ${ }^{1,3 *}$ Andrés Miguez, ${ }^{1,3 *}$ Maria Savvaki, ${ }^{6}$ Grégoire Levasseur, ${ }^{3,4}$ Aude Muzerelle,, 3 \\ Marie-Paule Muriel, ${ }^{2,3}$ Olivier Goureau, ${ }^{3,5}$ Kazutada Watanabe, ${ }^{7}$ Laurence Goutebroze, ${ }^{3,4}$ Patricia Gaspar, 3,4 \\ Bernard Zalc, ${ }^{1,3}$ Domna Karagogeos, ${ }^{6}$ and Jean-Léon Thomas ${ }^{1,3}$ \\ ${ }^{1}$ Institut National de la Santé et de la Recherche Médicale (INSERM), Unité 711, ${ }^{2}$ INSERM, Unité 679, ${ }^{3}$ Université Pierre et Marie Curie, Faculté de \\ Médecine, Hôpital de la Salpêtrière, Institut Fédératif de Recherche 70, F-75013 Paris, France, ${ }^{4}$ INSERM, Unité 839, Institut du Fer à Moulin, F-75005 Paris, \\ France, ${ }^{5}$ INSERM, Unité Mixte de Recherche en Santé 592, Hôpital Saint-Antoine, F-75012 Paris, France, 6 University of Crete Medical School and Institute \\ of Molecular Biology and Biotechnology, 71110 Heraklion, Greece, and ${ }^{7}$ Department of Bioengineering, Nagaoka University of Technology, Kamitomioka, \\ Nagaoka, Niigata 940-2188, Japan
}

White matter axons organize into fascicles that grow over long distances and traverse very diverse environments. The molecular mechanisms preserving this structure of white matter axonal tracts are not well known. Here, we used the optic nerve as a model and investigated the role of TAG-1, a cell adhesion molecule expressed by retinal axons. TAG-1 was first expressed in the embryonic retinal ganglion cells (RGCs) and later in the postnatal myelin-forming cells in the optic nerve. We describe the consequences of genetic loss of Tag-1 on the developing and adult retinogeniculate tract. Tag-1-null embryos display anomalies in the caliber of RGC axons, associated with an abnormal organization of the astroglial network in the optic nerve. The contralateral projections in the lateral geniculate nucleus are expanded postnatally. In the adult, Tag-1-null mice show a loss of RGC axons, with persistent abnormalities of axonal caliber and additional cytoskeleton and myelination defects. Therefore, TAG-1 is an essential regulator of the structure of RGC axons and their surrounding glial cells in the optic nerve.

Key words: CAM; retinal ganglion cell; optic nerve; axon; myelin; astrocyte

\section{Introduction}

The CNS white matter forms a backbone of axonal fiber tracts connecting groups of neurons with their synaptic target. During the embryonic and neonatal periods of development, the tract fibers cross a variety of brain environments along their pathway and establish contacts with neighboring glial cells (Van Vactor, 1998). Their structural organization depends especially on cell adhesion molecules (CAMs), a family of glycoproteins expressed at the surface of growth cones and axons, which contribute to adhesion and fasciculation (Rathjen et al., 1987) and are coreceptors of axonal signaling systems (Lagenaur and Lemmon, 1987; Bartsch et al., 1989; Schachner, 1991; Castellani et al., 2002; Oster et al., 2004).

\footnotetext{
Received March 13, 2008; revised June 6, 2008; accepted June 9, 2008.

This work was supported by Institut National de la Santé et de la Recherche Médicale and the European Leukodystrophy Association (ELA). E.C. was a fellow of the Ministère de I'Enseignement Supérieur et de la Recherche and ELA. A.M. was a fellow of the Fundación Pedro Barrié de la Maza and Association pour la Recherche sur la Sclérose en Plaques. M.S. is a PhD candidate in the Molecular Medicine Graduate Program of the University of Crete Medical School. We are grateful to C. Mason, A. Rebsam, V. Castellani, F. Mann, and A. Trembleau for stimulating discussions, to T. Sakurai and E. Di Lullo for their careful reading of this manuscript, to D. Langui and C. Carteron for technical assistance in EM studies and RGC cultures, and to A. Furley for providing Tag- 1 knock-in embryos.

${ }^{*}$ E.C. and A.M. contributed equally to this work.

Correspondence should be addressed to Jean-Léon Thomas, Unité Mixte de Recherche, Institut National de la Santé et de la Recherche Médicale, Unité 711, UniversitéPierre et Marie Curie, Hôpital de la Salpêtrière, 47 boulevard de l'Hôpital, F-75651 Paris Cedex 13, France. E-mail: jean-leon.thomas@upmc.fr.

DOI:10.1523/JNEUROSCI.1103-08.2008

Copyright $\odot 2008$ Society for Neuroscience $\quad$ 0270-6474/08/287624-13\$15.00/0
}

Interestingly, several CAMs can be expressed by both axons and glial cells (Traka et al., 2002; Mann et al., 2004), suggesting that they have a dual function during the development of white matter tracts, first for the structure of axonal tracts, and then for axon-glia interactions. Axonin-1/TAG-1/Contactin-2 is one of these molecules. It is a GPI (glycosylphosphatidylinositol)-linked molecule of the Ig/fibronectin type-III CAM subfamily implicated in neurite outgrowth (Ruegg et al., 1989; Furley et al., 1990; Stoeckli et al., 1991; Stoeckli and Landmesser, 1995). It is also expressed by Schwann cells and oligodendrocytes (Traka et al., 2002). TAG-1 can bind homophilically to neighboring cells (Rader et al., 1993; Tsiotra et al., 1996; Kunz et al., 2002), or interact heterophilically with other CAMs, such as L1 (Lemmon et al., 1989; Kuhn et al., 1991; Felsenfeld et al., 1994; Malhotra et al., 1998), NgCAM-related cell adhesion molecule (Nr-CAM) (Suter et al., 1995; Stoeckli et al., 1997; Lustig et al., 2001; Pavlou et al., 2002), or neural cell adhesion molecule (NCAM) (Milev et al., 1996).

To examine whether TAG-1 plays a dual role during white matter tract development, first on the development of axons, and then in axon-glia interactions, we focused on the optic nerve, in which TAG-1 expression has already been reported in several species of vertebrates (Wolfer et al., 1994; Morino et al., 1996; Rager et al., 1996; Lang et al., 2001; Williams et al., 2006). The optic nerve is formed, from embryonic day 12.5 (E12.5) to birth in the mouse, by the axons of retinal ganglion cells (RGCs). From 
E14.5 to neonatal stages, these RGC axons are progressively surrounded by differentiating astroglial cells (Mi and Barres, 1999; Liu and Neufeld, 2004) and the oligodendrocyte precursor cells that migrate from the preoptic region of the forebrain (Small et al., 1987; Ono et al., 1997; Spassky et al., 2002). We have thus investigated a potential role for TAG-1 in the development of RGC axons in the embryo and myelination in the adult optic nerve.

We analyzed the spatiotemporal expression of Tag- 1 by murine RGCs and examined the retinogeniculate tract (RGT) of Tag-1 mutant mice at embryonic, neonatal, and adult stages. Tag-1 showed a biphasic pattern of expression in both the developing RGCs at embryonic stages and then in the optic nerve oligodendrocytes postnatally. In the Tag-1 $1^{-1-}$ embryo, RGCs axons displayed morphological anomalies of caliber size, whereas the astroglial network extended abnormally in the optic nerve. Finally, adult Tag-1-null mutants showed persistent structural defects of RGC axons in the optic nerve, such as an increased caliber and a reduced cytoskeleton, associated with abnormalities of myelination. Collectively, these results indicate that TAG-1 has multiple roles in the development and/or maintenance of RGCs, axo-axonal and axo-glia interactions in the optic nerve.

\section{Materials and Methods}

Animals. Tag-1 mutant mice (Fukamauchi et al., 2001) were kept as heterozygous breeding pairs. All genotypes were confirmed by PCR.

Tissue preparation for in situ hybridization and immunohistochemistry. Freshly collected embryos (E11.5-E18.5), postnatal [postnatal day 0 (P0) to $\mathrm{P} 12$ ] and adult mice were fixed with $4 \%$ paraformaldehyde (PFA) in PBS.

The fixed tissue was cryoprotected in PBS/20\% sucrose, and then embedded in either OCT or 15\% sucrose/7.5\% gelatin in PBS before freezing. Coronal or horizontal cryosections (14-20 $\mu \mathrm{m}$ thick) were performed before antibody and/or in situ hybridization labeling.

Immunohistochemistry, in situ hybridization. The following antibodies were used: anti-NaV (1:200; Sigma-Aldrich), anti-Caspr/paranodin (PND) (1:250) (Menegoz et al., 1997) (kindly provided by L. Goutebroze, INSERM U839, Paris, France), anti-Glast (1:100; Millipore Bioscience Research Reagents), anti-GFAP (1:400; Dako), anti-A2B5 (1:10; Hybridoma Bank), anti-L1 (1:400; Millipore Bioscience Research Reagents), anti-Brn3a (1:400; Millipore Bioscience Research Reagents), anti-Olig2 (1:200; Millipore Bioscience Research Reagents), anti-Pax2 (1:100; Covance), anti-TAG-1 (1:4; 4D7; Developmental Studies Hybridoma Bank), and anti-Neurofilament antibodies for phosphorylated epitope (SMI-31) and nonphosphorylated epitope SMI-32 (1:400; Sternberger Monoclonal Antibodies).

In situ hybridization was performed using a mouse Tag- 1 cDNA, as reported by Traka et al. (2002).

Primary cell cultures. E14.5 retinas were dissected and sectioned at $250 \times 250 \mu \mathrm{m}$ with a McIlwain tissue chopper. Explants were cultured on CHO or CHO-TAX cells (Traka et al., 2003) seeded the previous day, with DMEM/F12 culture medium supplemented with $0.1 \%$ BSA, $1 \%$ fetal calf serum, N2 (1:100; Invitrogen), B50 (1:50; Invitrogen), and 0.4\% methylcellulose (Sigma-Aldrich). Axon density index corresponds to the ratio between the intensity of fluorescence of labeled neurites (quantified with MetaMorph software) and the surface covered by labeled neurites.

For dissociated retinal cells, cultures were grown on poly-L-lysine and laminin-coated $12 \mathrm{~mm}$ glass coverslips. Retinas from E14.5 embryonic mice were dissociated with Accumax (Sigma-Aldrich), and cells were cultured in DMEM/F12 medium supplemented with HEPES, 0.1\% BSA, and $1 \%$ fetal bovine serum.

E17.5 or E18.5 optic nerves were dissociated with papain $\left(15 \mathrm{U} \mathrm{ml}^{-1}\right.$; Worthington) and collagenase (27 $\mathrm{U} \mathrm{ml}^{-1}$; Sigma-Aldrich), and cells were seeded on Terasaki 60 -well microplates coated with poly-L-lysine (500 cells per well) in Bottenstein and Sato's modified culture medium (BS) (1\% fetal calf serum and $9.3 \mu \mathrm{g} \mathrm{ml}^{-1}$ insulin). We used TAG-1 (10 $\mu \mathrm{g} \mathrm{ml}^{-1}$; R\&D Systems), and basic fibroblast growth factor (bFGF) (20 ng ml ${ }^{-1}$; Roche).

Stripe assays. Stripe assays were performed as described previously (Prestoz et al., 2004). Purified human TAG-1 or NCAM-L1 $(10 \mu \mathrm{g} / \mathrm{ml}$; R\&D Systems) and laminin (40 and $10 \mu \mathrm{g}$ ml-1; Sigma-Aldrich) were used for stripe coating on coverslips. Retinal explants (E14.5) or dissociated optic nerve cells (E18.5) were cultured for $2 \mathrm{~d}$ in vitro (DIV), fixed with $4 \%$ PFA, and immunolabeled either with anti-Neurofilament antibodies, or with GFAP or A2B5 Ab, respectively.

Electron microscopy. Anesthetized mice were perfused with $2.5 \%$ glutaraldehyde $/ 2 \%$ paraformaldehyde or $0.1 \%$ glutaraldehyde $/ 4 \%$ paraformaldehyde. Dissected optic nerves were placed in the chosen fixative overnight at $4^{\circ} \mathrm{C}$. Samples were postfixed in $1 \%$ osmium tetroxide, stained in $1 \%$ uranyl acetate, dehydrated, and embedded in Epon. Semithin sections $(0.5 \mu \mathrm{m})$ were prepared and stained with toluidine blue. Ultrathin sections $(70 \mathrm{~nm}$ ) were cut on an ultramicrotome (Ultracut E; Reichart-Jung), contrasted with 3\% uranyl acetate and 5\% lead citrate, and viewed by a JEOL 1200 EX electron microscope with Analysis Docu software. For ultrastructural studies, randomly chosen electron micrographs were taken at 10,000,30,000, 40,000, and 60,000× magnification in both the center and the periphery within the medial segment of the optic nerve. Axon diameter and myelin thickness were measured using MetaMorph software for digital tracing. The number of microtubules, neurofilaments and myelin lamellae was counted manually.

Anterograde labeling of RGC axonal projections. Postnatal mice (P7) were anesthetized intraperitoneally and eyes were injected with the $\mathrm{B}$ subunit of cholera toxin $(1 \%$ in $0.9 \% \mathrm{NaCl})$ coupled either to Alexa 488 (left eye) or Alexa 594 (right eye) (Invitrogen). After $48 \mathrm{~h}$, brains were sectioned with a freezing microtome (Leica SM2000 R). The surfaces of ipsilateral and contralateral projections in the dorsal lateral geniculate nucleus (dLGN) were measured with MetaMorph software on photographs of consecutive coronal sections (five for each animal, taken with a Zeiss fluorescence microscope), always localized similarly at midlevel of the dLGN, as reported by Ravary et al. (2003).

Western blot analysis and immunoprecipitation. Tissues were harvested from freshly killed mice and either frozen or homogenized directly in ice-cold 85 mm Tris, pH 7.5, 30 mm NaCl, 1 mm EDTA, 120 mm glucose, $1 \%$ Triton X-100, $60 \mathrm{~mm}$ octyl $\beta$-D-glucopyranoside (Sigma-Aldrich), and $1 \mathrm{~mm}$ PMSF (Sigma-Aldrich), followed by a brief sonication on ice. The protein extract was analyzed on a SDS-polyacrylamide gel and transferred to a $0.45 \mu \mathrm{m}$ Protran nitrocellulose transfer membrane (Whatman Schleicher and Schuell; Bioscience) over $1 \mathrm{~h}$ using a wet transfer unit (Bio-Rad). After blocking (5\% powdered skim milk and $0.1 \%$ Tween 20 in PBS) for $1 \mathrm{~h}$, the blots were incubated overnight at $4^{\circ} \mathrm{C}$ with the following primary antibodies: rabbit polyclonal antibody against TAG-1 (TG2; 1:4000), rabbit polyclonal antibody against L1 (1:3000; from Dr. F. Rathjen, Max Delbrück Center for Molecular Medicine, Berlin, Germany), mouse monoclonal $\beta$ III-tubulin antibody (Tuj1; 1:2000; SigmaAldrich), mouse monoclonal antibodies against phosphorylated and nonphosphorylated neurofilaments $\mathrm{H}$ and L (SMI31 and SMI32, respectively; 1:1000; Sternberger Monoclonal Antibodies), mouse monoclonal antibody against microtubule-associated protein 2 (MAP-2) (1:1000; Sigma-Aldrich), rabbit polyclonal antibody against neurofilaments $M$ (NF-M) (1:5000; Covance), and mouse monoclonal against actin (1:3000; Millipore Bioscience Research Reagents). After washing three times for $10 \mathrm{~min}$ in $0.1 \%$ Tween 20 in PBS, and incubation with horseradish peroxidase-coupled secondary antibodies (1:3000-5000; Roche Diagnostics) for $1 \mathrm{~h}$ at room temperature, the blots were visualized by enhanced chemiluminescence (Millipore Bioscience Research Reagents). The band intensity was measured with Tinascan software, version $2.07 \mathrm{~d}$. For the immunoprecipitation, we used protein extracts, processed as previously mentioned, from optic nerves of 10 E18.5 mice, protein A-agarose beads (Bio-Rad), and $5 \mu$ l of a rabbit anti-TAG-1 polyclonal antibody.

Statistical analysis. InStat software was used for statistical analysis, and data were compared using either Student's $t$ test, Mann-Whitney's $U$ test, or alternate Welch's $t$ test. Significant $p$ values are indicated by asterisks in the figures $\left({ }^{*} p<0.05 ;{ }^{* *} p<0.01 ;{ }^{* * *} p<0.001\right)$. 


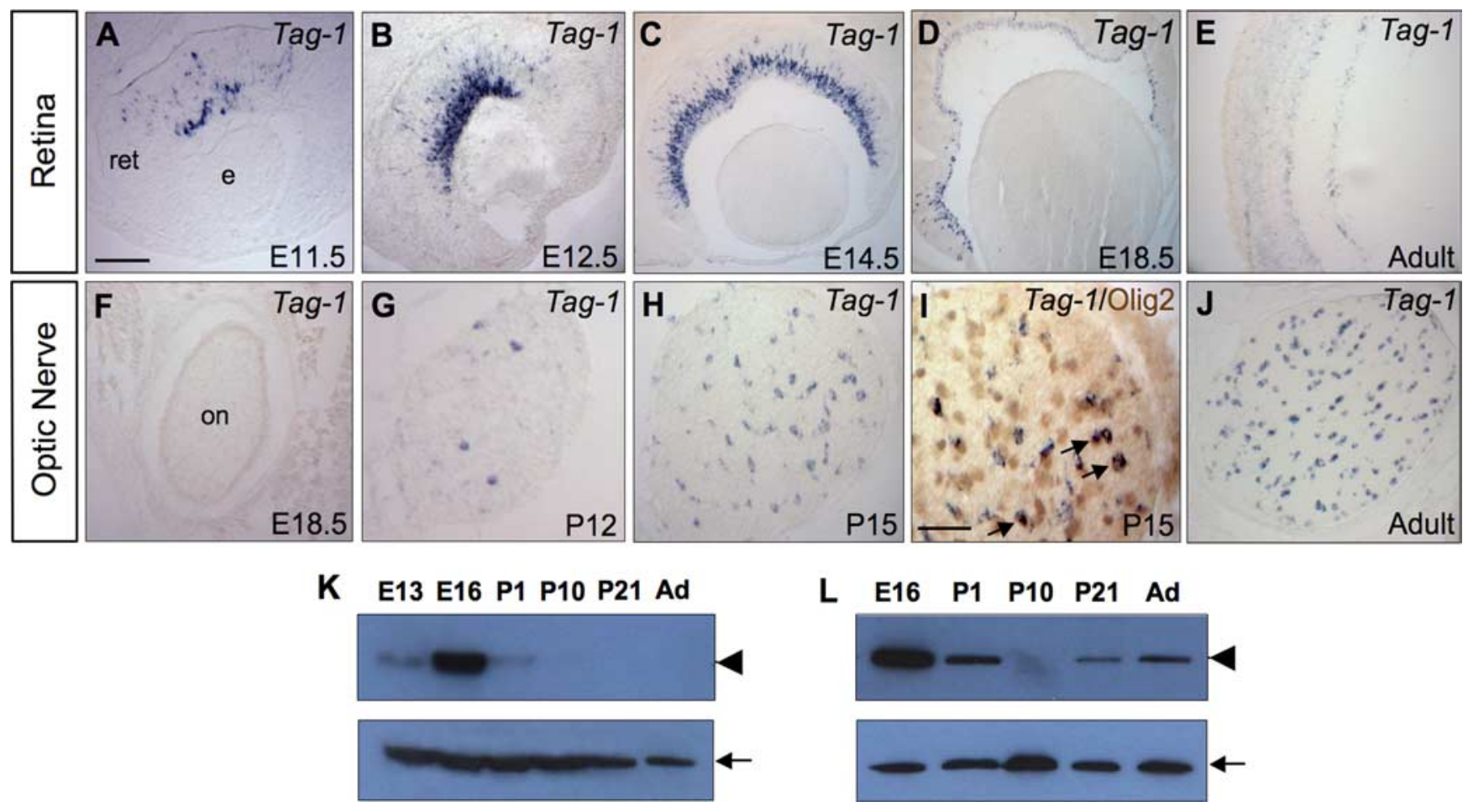

Figure 1. Tag-1 expression during retina and optic nerve development. $\boldsymbol{A}-\boldsymbol{J}$, In situ hybridization with a Tag-1 antisense riboprobe on cryosections of retina $(\boldsymbol{A}-\boldsymbol{E})$ and optic nerve $(\boldsymbol{F}-\boldsymbol{J})$. $\boldsymbol{A}-\boldsymbol{C}$, Retinal expression of Tag- 7 is restricted to the inner layer and expands from the center toward the periphery between E11.5 and 14.5. At E18.5, Tag-7 is only expressed in the ventrotemporal crescent (D). Only a weak expression of Tag-1 is detectable at postnatal and adult stages $(\boldsymbol{E})$. $\boldsymbol{F}$-J, In the optic nerve, Tag-1-expressing cells are absent during the embryonic period $(\boldsymbol{F})$ and detected from P12 onwards $(\mathbf{G})$. $\boldsymbol{H}, \boldsymbol{I}$, Merged image of serial coronal cryosections of the nerve labeled with a Tag-1 riboprobe and an anti-0lig2 Ab, showing that Tag-7-expressing cells include numerous 0 lig2 ${ }^{+}$ oligodendrocytes $\left(\boldsymbol{I}\right.$, arrows point at double-labeled cells, 0 lig $\left.2^{+} / \mathrm{Tag}-1^{+}\right)$. $\boldsymbol{J}$, Tag-1-expressing cells in the adult optic nerve. $\boldsymbol{K}, \boldsymbol{L}$, Western blot analysis of TAG-1 expression in the retina and optic nerve at the indicated embryonic and postnatal stages. In the retina, TAG-1 protein (arrowhead; $130 \mathrm{kDa}$ ) expression increases during development, with a high expression at E16, whereas it is not detected at postnatal stages after P1. In the optic nerve, TAG-1 expression is very high at E16 but significantly decreases by P10 and reappears at late postnatal stages and in adulthood. Actin (arrow) was used as an internal loading control. ret, Retina; e, eye. Scale bars: $A-H, J, 100 \mu \mathrm{m} ; I, 50 \mu \mathrm{m}$.

\section{Results}

Expression of Tag-1 by embryonic RGCs and postnatal oligodendrocytes in the optic nerve

The time course of Tag-1 expression in the retina and optic nerve system was examined by in situ hybridization with a Tag-1 antisense riboprobe (Fig. 1A-J). In the embryo, Tag-1 transcripts were only detected in the retina. The earliest detection was at E11.5 in the central part of the retina where the first RGCs are born (Dräger, 1985) (Fig. 1A). From E14.5, a time point corresponding to the peak of RGC production, the expression pattern of Tag-1 had spread toward the periphery of the retina, but remained mostly located in the RGClayer (Fig. $1 B, C$ ). At E18.5, the intensity of the Tag-1 signal was weaker in the RGC layer of the dorsal retina, than in the ventrotemporal crescent, which generates a late pool of RGCs (Dräger, 1985; Colello and Guillery, 1990; Williams et al., 2006) (Fig. 1D). Postnatally and in the adult, Tag-1 expression was downregulated in RGCs of all retinal crescents (Fig. 1E). Thus, the pattern of Tag-1 coincides with the known centroperipheral gradient of maturation of the retina, rather than with a specific localization of ipsilateral/contralateral RGCs. In the optic nerve, Tag-1 transcripts were not detected during the embryonic period (Fig. $1 F$ ). From P12 until the adult stage, Tag-1 expression was detected in dispersed cells within the nerve (Fig. $1 G-J$ ), identified as Olig2-expressing oligodendroglial cells, in agreement with a previous report (Traka et al., 2003) (Fig. 1I). It is worthy to note that the expression of Tag-1 by oligodendrocytes was delayed compared with the onset of myelination, which starts at P6 in the mouse optic nerve (Demerens et al., 1996), and only in approximately one-half of Olig2 ${ }^{+}$cells (Charles et al., 2000).

The detection of Tag- 1 transcripts during retina and optic nerve development correlated with the expression of TAG-1 protein, as illustrated by Western blot analysis of extracts from retina (Fig. $1 \mathrm{~K}$ ) and optic nerve (Fig. $1 \mathrm{~L}$ ), showing a strong $130 \mathrm{kDa}$ band corresponding to TAG-1 protein in the embryonic retina, between $\mathrm{E} 13$ and P1, as well as in the optic nerve at both embryonic and adult stages (not detected at P10).

To determine where TAG-1 protein was expressed during RGT development, we performed immunolabeling of the retina and the optic tract (Fig. 2A-M). Retinal cryosections and dissociated cell cultures were double-labeled with the anti-TAG-1 Ab and either the anti-Brn3a Ab or the anti-L1 Ab, marker of RGCs (McEvilly et al., 1996) and optic nerve fibers (Demyanenko and Maness, 2003), respectively (Fig. 2A-C). TAG-1 expression was almost exclusively detected on neurites of $\mathrm{Brn} \mathrm{a}^{+}$RGCs, which formed fascicles at the surface of the RGC layer. Moreover, whereas L1 was expressed by almost all RGC axons, TAG-1 expression was restricted to a subpopulation of $\mathrm{L}^{+}{ }^{+} \mathrm{RGC}$ axons. Additional whole-mount labeling of E14.5 and E18.5 retina $(n=$ 5 of each stage) showed that TAG-1 expression was temporally regulated in RGCs, starting from the onset of axon growth, and then rapidly declining at E18.5, when axons progressed toward their target (Fig. $2 D-J$ ). Finally, in the optic tract, we found RGC fibers strongly expressing TAG-1 in the embryonic nerve, the chiasm, and the optic tract within the diencephalon, as previously reported (Laub et al., 2005) (Fig. $2 K-M$ ). 

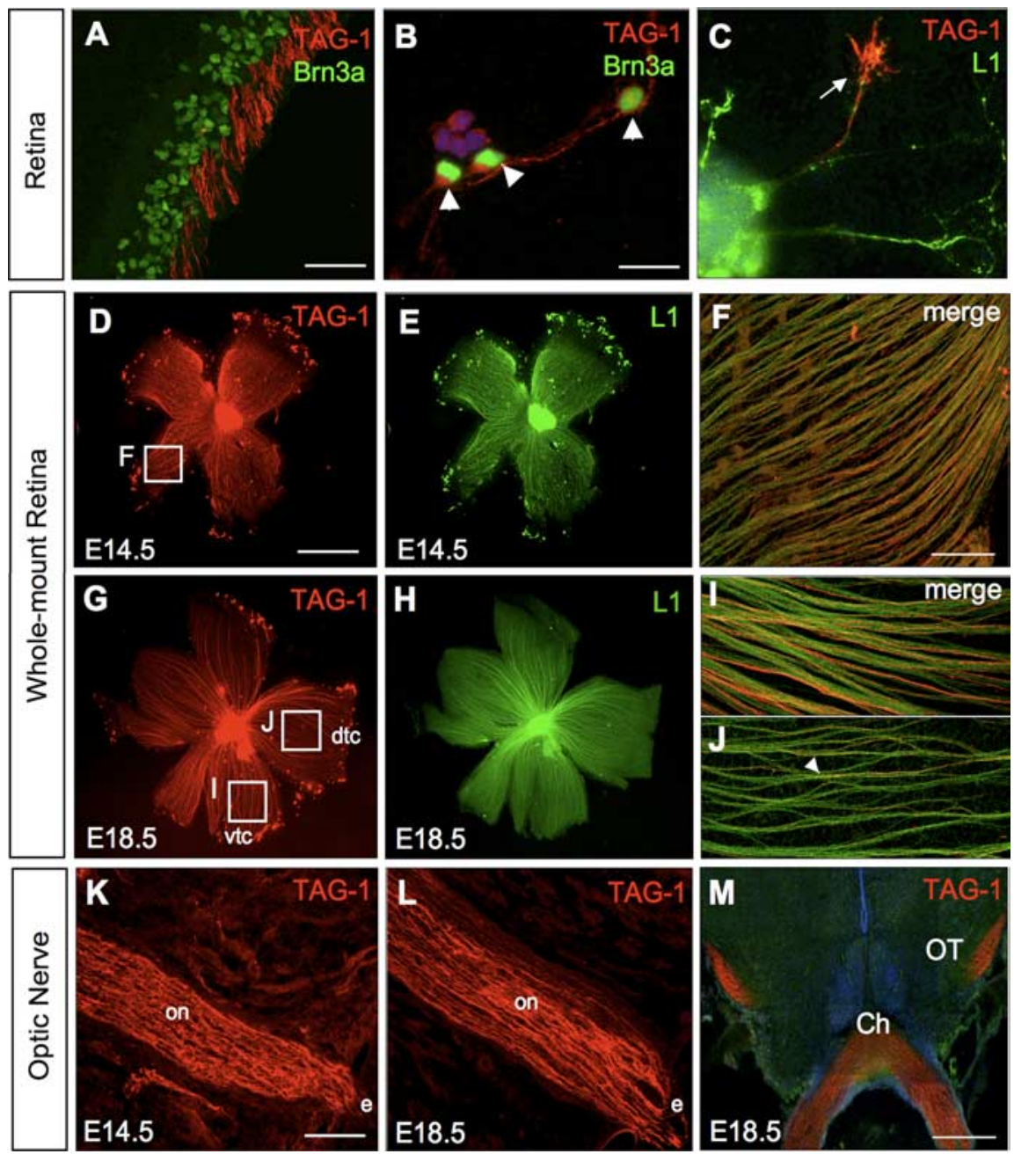

Figure 2. Axonal expression of TAG-1 during RGC development. $\boldsymbol{A}-\boldsymbol{C}$, Immunolabeling of cryosections and cultures of embryonic retina with anti-TAG-1 Ab (red). Retinal cryosections $(\boldsymbol{A}, \mathrm{E} 17.5)$ and dissociated retinal cells $(\boldsymbol{B}, \boldsymbol{C}, \mathrm{E} 14.5)$ are double labeled with the anti-Brn3a $\mathrm{Ab}(\boldsymbol{A}, \boldsymbol{B}$, green) or the anti-L1 Ab ( $\boldsymbol{C}$, green). Nuclei are stained with Hoechst dye (blue). TAG-1 is expressed by fascicles of axons emerging from groups of $B r n 3 a^{+} R G C s$ in the inner layer of retina $(\boldsymbol{A})$. In retinal cultures, expression of TAG- 1 is restricted to Brn3a ${ }^{+} \mathrm{RGC}$ bodies and axons ( $\boldsymbol{B}$, arrowheads) and subpopulations of $\mathrm{L} 1^{+}$axons ( $\boldsymbol{C}$, arrow). Note that TAG- 1 is more strongly expressed at the distal extremity of the axon and in the growth cone. $\boldsymbol{D}-\boldsymbol{J}$, Whole mounts of E14.5 and E18.5 retina double labeled with anti-TAG-1 (red) and -L1 (green) Abs. AtE14.5, TAG-1 and L1 are expressed by RGC axons in all quadrants of the retina $(\boldsymbol{D}, \boldsymbol{E})$ and appear coexpressed by the majority of RGC axons $(\boldsymbol{F})$. At E18.5, TAG-1 expression decreases, especially in the dorsal quadrants of the retina, both in nasal and temporal crescents $(\boldsymbol{G})$ in contrast to $L 1$, which remains uniformly detected $(\boldsymbol{H}) . \boldsymbol{I}, \boldsymbol{J}$, Confocal image magnifications of the boxed areas in $\mathbf{G}$ show a minor subpopulation of TAG- $1^{+} / \mathrm{L}^{+}{ }^{+} \mathrm{RGC}$ fibers (yellow) ( $\boldsymbol{J}$, arrowhead). $\boldsymbol{K}-\boldsymbol{M}$, Immunolabeling of the embryonic optic tract with the anti-TAG-1 Ab. Expression of TAG-1 by axonal fibers is observed all along the embryonic optic tract, as shown on horizontal cryosections of the optic nerve at E14.5 ( K) and E18.5 (L), and on a coronal cryosection of the diencephalon at E18.5 $(\boldsymbol{M})$. dtc, Dorsotemporal crescent; vtc, ventrotemporal crescent; on, optic nerve; e, eye; Ch, chiasm; 0T, optic tract. Scale bars: $\boldsymbol{M}, 400 \mu \mathrm{m} ; \boldsymbol{D}, \boldsymbol{E}, \boldsymbol{G}, \boldsymbol{H}, \boldsymbol{K}, \boldsymbol{L}, 100 \mu \mathrm{m} ; \boldsymbol{A}, \boldsymbol{F}, \boldsymbol{I}, \boldsymbol{J}, 50 \mu \mathrm{m} ; \boldsymbol{B}, \boldsymbol{C}, 10 \mu \mathrm{m}$.

In summary, Tag- 1 transcripts and protein are detected both in embryonic RGCs and postnatal myelinating cells of the optic nerve. In addition, TAG-1 is transiently expressed by young RGC axons expressing $\mathrm{L} 1$ and engaged in the formation of fascicles.

\section{TAG-1 mediates RGC axon fasciculation in vitro}

TAG-1 is an adhesion molecule promoting neurite outgrowth and possibly the fasciculation of developing axons (Dodd et al., 1988; Furley et al., 1990). Because TAG-1 was expressed by groups of RGC axons in the embryonic retina, we examined whether TAG-1 could promote the fasciculation of RGC axons in vitro.

We first performed stripe assays to examine the behavior of RGC axons on a TAG-1-coated substrate (Fig. $3 A-D$, Table 1).
Retinal explants were isolated at stage E14.5, when TAG-1 is expressed by the majority of RGC axonal fibers, and grown on stripes coated with laminin alone, or alternatively with TAG-1 and laminin (Fig. $3 A, B$ ). RGC axons, immunolabeled with anti-neurofilament Abs (SMI31/32), grew randomly on stripes coated with laminin at two different concentrations (10 and $40 \mu \mathrm{g} / \mathrm{ml}$ ). In contrast, axons adhered and grew preferentially on TAG-1-coated stripes (10 $\mu \mathrm{g} / \mathrm{ml}$ ) versus laminin-coated stripes. To determine whether the preference of RGC axons for TAG-1-coated substrate required the presence of TAG-1 on RGC axons, stripe assays were repeated with retinal explants from Tag-1-deficient mice (Fukamauchi et al., 2001) (Fig. 3C). Tag- $1^{-1-}$ axonal fibers showed no preference for either set of lanes on either TAG-1- or laminin-coated stripes. Additional observations suggested that the strong interactions mediated by TAG-1 could act in trans between RGC axons and regulate their fasciculation. Notably, RGC axons crossing stripes fasciculated on laminin, and then defasciculated when they contacted TAG-1coated stripes (Fig. 3D).

In a second series of experiments, we performed a "cell-to-cell" contact assay to examine the effect of TAG-1-expressing cells on RGC axons (Fig. $3 E-H$ ). E14.5 retinal explants were cultured on a monolayer of CHO cells stably expressing TAX (human homolog of TAG-1) (Kozlov et al., 1995; Pavlou et al., 2002) (supplemental Fig. $1 A$, available at www.jneurosci.org as supplemental material) or control $\mathrm{CHO}$ cells. In contact with TAXproducing cells, the neurites showed unchanged growth rate compared with controls (surface of explant plus neurites/surface of explant \pm SEM: $\mathrm{CHO}$, $39.3 \pm 2.2$; CHO-TAX-1, $45.3 \pm 3.3$ ), although they appeared to be more numerous (axon density index \pm SEM: CHO, $22.3 \pm 0.9$; CHO-TAX-1, $17.9 \pm$ 0.9 ; Student's $t$ test, ${ }^{*} p<0.05$; number of explants/experiment $\geq 10 ; n=3$ ).

We next examined whether L1, a CAM expressed on the majority of RGC axons and a TAG-1 partner (Malhotra et al., 1998), also promotes RGC fiber adhesion and interacts with TAG-1 in this process (Fig. 3I, J, Table 1). On stripes of laminin alone or coated with L1, the RGC axons preferred to grow on L1-coated stripes. Notably, axons of Tag- $1^{+/-}$or Tag- $1^{-1-}$ RGCs behaved similarly, indicating that TAG-1 is not required for their adhesion on L1, and that the strong outgrowth-promoting effect of L1 allows the RGC axons to, at least partially and in vitro, grow independent of TAG-1. Finally, we performed immunoprecipitation experiments on E18.5 optic nerve extracts to detect possible binding interactions between TAG-1 and L1 in vivo, but we 

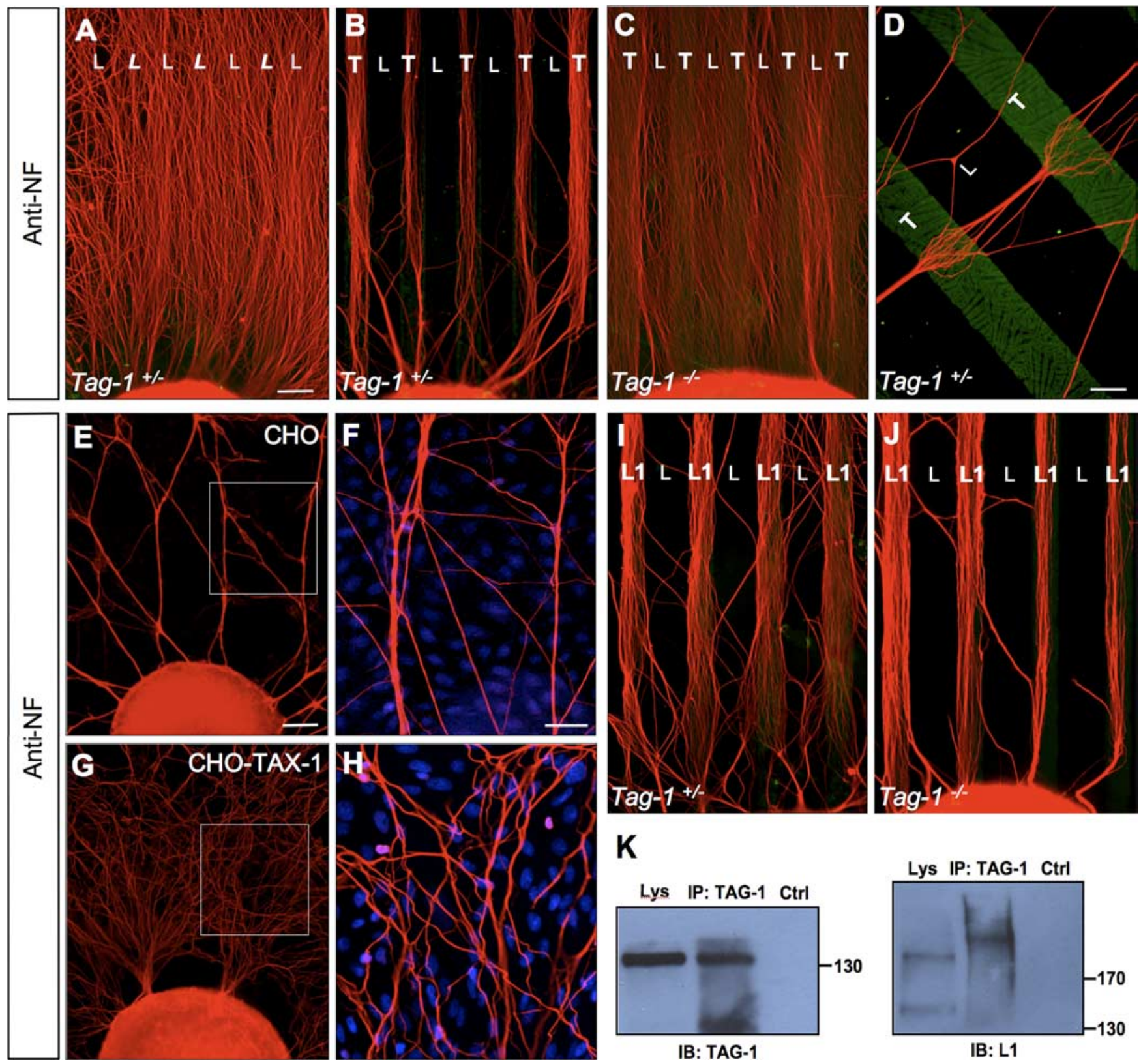

\section{K}

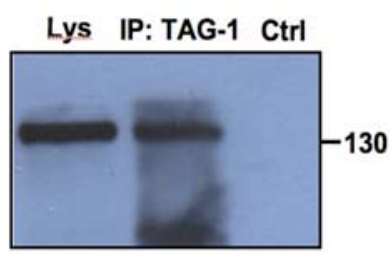

IB: TAG-1

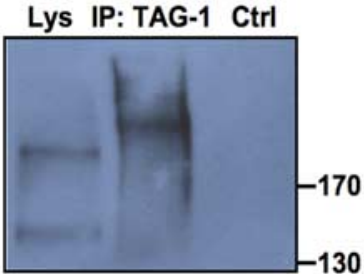

IB: L1

Figure 3. RGC axon fasciculation requires homophilic TAG-1 interactions in vitro. $A-D$, Assays of RGC axonal growth performed on stripes coated alternatively with laminin alone ( $\boldsymbol{A})$ or with TAG-1 $(\boldsymbol{B}-\boldsymbol{D})$. Retinal explants were isolated from E14.5 Tag- $1^{+/-}(\boldsymbol{A}, \boldsymbol{B}, \boldsymbol{D})$ or Tag- $1^{-1-}(\boldsymbol{C})$ embryos. RGC axons were immunolabeled with SMI31/32 anti-NF Abs (red). $\boldsymbol{A}$, Tag- $1^{+/-}$axons grow equally

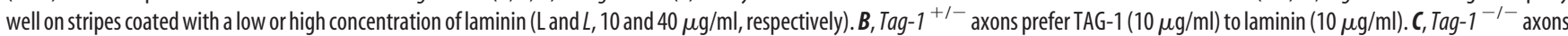
display no preference between TAG-1- and laminin-coated stripes. $\boldsymbol{D}$, Typical defasciculation behavior of RGC axonal bundles as they cross TAG-1-coated stripes (retinal explant at the bottom left of the picture). L, Laminin; T, TAG-1. $\boldsymbol{E}-\boldsymbol{H}$, Cell-to-cell contact assays performed with E14.5 retina explants cultured on a monolayer of $\mathrm{CHO}$ cells $(\boldsymbol{E}, \boldsymbol{F})$, or of $\mathrm{CHO}$ cells stably expressing TAX-1 ( $\boldsymbol{G}, \boldsymbol{H})$. RGC axons are immunolabeled with anti-NF Abs (red), and CHO cell nuclei are stained with Hoechst (blue) on high-magnification pictures $(\boldsymbol{F}, \boldsymbol{H})$. RGC axons exiting from the retinal explants were thinner, more branched and numerous at the contact of TAX-1-expressing cells (blue nuclei). $I, J$, Stripe assays of RGC axons isolated from E14.5 Tag- $1^{+/-}(I)$ or Tag- $1^{-I-}(J)$ embryos on stripes coated with either laminin, or L1. TAG-1-deficient axons show a similar preference for L1 substrate than controls. $K$, Immunoprecipitation (IP) of TAG-1 from protein extracts of E18.5 optic nerves and immunoblotting with antibodies against L1 and TAG-1. Optic nerves lysate (input), TAG-1 IP, and control IP (preimmune rabbit serum) are labeled with the anti-TAG-1 (left panel) and anti-L1 (right panel) Abs. No TAG-1/L1 complex was detected. IB, Immunoblot; Lys, lysate. Scale bars: $\boldsymbol{A}-\boldsymbol{C}, \boldsymbol{E}, \boldsymbol{G}, \boldsymbol{I}, \boldsymbol{J}, 100 \mu \mathrm{m} ; \boldsymbol{D}, \boldsymbol{F}, \boldsymbol{H}, 50 \mu \mathrm{m}$.

found no evidence of a TAG-1/L1 complex on embryonic RGC axons (Fig. $3 K$ ).

Together, these in vitro studies provide strong evidence for a potent role of TAG-1 in the adhesion and fasciculation behaviors of RGC axons, apparently independent of L1. They suggest that the loss of Tag- 1 could affect axon guidance or targeting in the RGT, as it has been already reported for the disruption of Nr-CAM (Zelina et al., 2005; Williams et al., 2006). To investigate this issue, we used a Tag1-deficient mouse. RGC axons of Tag- $1^{+/-}$and Tag-1 ${ }^{-/-}$neonates
(P9; $n=5$ of each type) from both eyes were anterogradely labeled with cholera toxin-594 (red) and cholera toxin-488 (green) (Fig. $4 A$ ). In the Tag- 1 homozygotes, the ipsilateral and contralateral optic fibers separated correctly at the optic chiasm (Fig. 4B), and their projection fields did not overlap in the dorsal LGN (Fig. 4E,F). However, we found a slight increase of the contralateral projection area, without ipsilateral anomaly, in comparison with heterozygote controls (Fig. 4C,F, Table 2). The neonatal pattern of RGC projections in the LGN was thus mildly affected in the absence of Tag-1. 
Table 1. Evaluation of the growth behavior of RGC axons on a laminin-coated substrate in protein stripe assay

\begin{tabular}{|c|c|c|c|c|}
\hline \multirow[b]{3}{*}{ Category } & \multicolumn{4}{|c|}{ Percentage of total explants } \\
\hline & \multicolumn{2}{|c|}{ TAG-1 + Lam vs Lam } & \multirow{2}{*}{$\frac{\text { Lam vs Lam }}{\operatorname{Tag}-1^{+/-}}$} & \multirow{2}{*}{$\frac{\mathrm{L} 1+\text { Lam vs Lam }}{\operatorname{Tag-1^{-/-}}}$} \\
\hline & $\operatorname{Tag}-1^{+/-}$ & $\operatorname{Tag}-1^{-1-}$ & & \\
\hline 3 & 94.44 & 0 & 0 & 100 \\
\hline 2 & 0 & 0 & 0 & 0 \\
\hline 1 & 5.55 & 16.66 & 0 & 0 \\
\hline 0 & 0 & 83.33 & 100 & 0 \\
\hline
\end{tabular}

The explants were classified into four categories (0 -3) as described by von Boxberg et al. (1993), in which 0 was no bias for either set of lanes and 3 was a strong choice. Lam, Laminin. $n \geq 4$ for each experiment, $5-6$ explants per experiment.
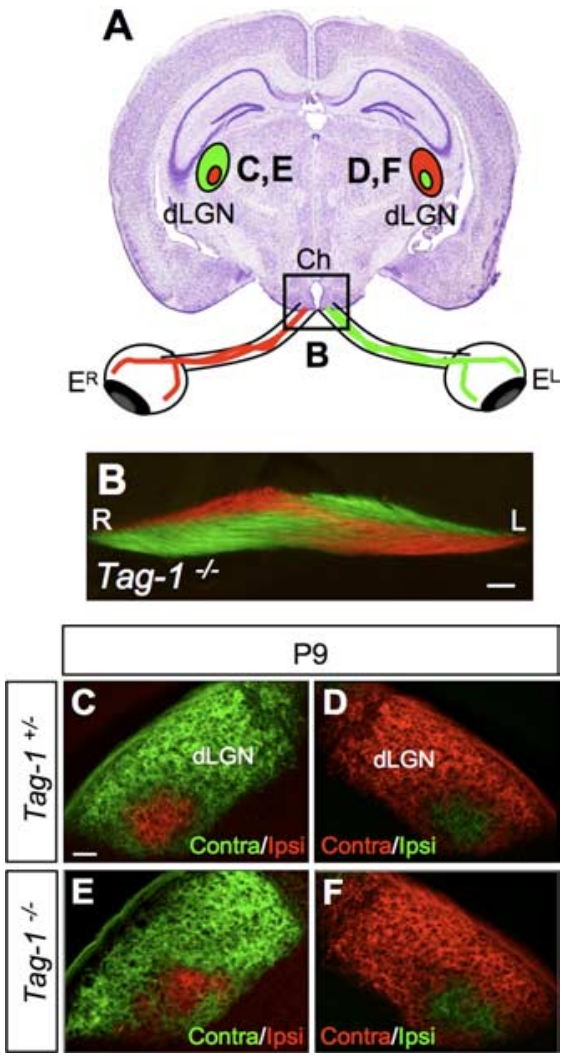

Figure 4. Abnormal contralateral projections in the Tag-1 ${ }^{-1-}$ LGN. RGC projections in Tag$1^{+1-}$ and $\mathrm{Tag}-1^{-1-}$ neonates were analyzed after anterograde labeling with cholera toxin594 (ChT-red) and cholera toxin-488 (ChT-green). ChT injection was performed in the right and left eye, respectively, at P7, and the pattern of fluorescent RGC axons was examined at P9. $\boldsymbol{A}$, Schematic representation of the RGT indicating the localization of regions illustrated in $\boldsymbol{B}-\boldsymbol{F}$. $\boldsymbol{B}$, Coronal cryosection of the chiasm showing that ipsilateral and contralateral axons segregate normally at the midline in the $T a g-1^{-1-}$ mouse. L, Left; $R$, right. $\mathbf{C}-\boldsymbol{F}$, Coronal sections in the anterior region of the dorsal $L G N$ of $\operatorname{Tag}-1^{+/-}(\boldsymbol{C}, \boldsymbol{D})$ and $\operatorname{Tag}_{-1}{ }^{-1-}(\boldsymbol{E}, \boldsymbol{F})$ mice display fluorescent-labeled ipsilateral and contralateral projections of RGCs. dLGN, Dorsal lateral genic ulate nucleus; $C h$, chiasm; $E^{R}$, right eye; $E^{L}$, left eye. Scale bar: $\boldsymbol{B}-\boldsymbol{F}, 100 \mu \mathrm{m}$.

\section{Abnormal caliber distribution and cytoskeletal defects of Tag-1 ${ }^{-1-}$ RGC axons}

We next examined the structure of RGC axons in the optic nerve of Tag-1-deficient mice. Ultrastructural studies were performed on coronal sections of embryonic and adult nerves isolated from heterozygous and homozygous Tag-1 mutants. At stage E18.5, when all RGC axons have been generated and while TAG-1 is still expressed in the nerve, the Tag-1 $1^{-1-}$ nerve showed more large and fewer small-caliber axons, with a slight lack of compaction between the axonal and cellular components of the nerve (Fig. $5 A, B)$. The density and caliber of RGC axons was quantified in Tag- $1^{+/-}$and Tag- $1^{-1-}$ genotypes $(n=3$ animals each; $>1000$ axons for each genotype). Tag- $1^{-1-}$ optic nerve displayed a $20 \%$ decrease in axonal density, suggesting that axonal compaction was impaired (number of axons $/ \mu \mathrm{m}^{2}$ \pm SEM: $\operatorname{Tag}-1^{+/-}, 10.3 \pm 0.6$; Tag- $1^{-/-}$, $\left.7.7 \pm 0.5 ;{ }^{* *} p<0.01\right)$. The average caliber of RGC axons was increased by $\sim 20 \%$ compared with the heterozygote control. A detailed classification of RGC axons showed a $50 \%$ reduction in the proportion of small axons $(<200 \mathrm{~nm})$ and a doubling of large axons $(>300 \mathrm{~nm})$ in the Tag-1 optic nerve compared with controls (Fig. 5C).

The adult Tag- $1^{-1-}$ nerve showed apparently normal tissue compaction, but few small-caliber axons compared with controls (Fig. $5 D, E$ ). Axonal density was decreased by $20 \%$ (Fig. $5 F$ ), suggesting a slight loss of RGC axons in the nerve (mean RGC axon number \pm SEM: Tag- $1^{+/-}, 24.9 \times 10^{3} \pm 1285$; Tag- $^{-/-}$, $19.5 \times 10^{3} \pm 2976$; average surface per optic nerve section $\left(\mu \mathrm{m}^{2}\right) \pm$ SEM: Tag- $1^{+/-}, 50.9 \times 10^{3} \pm 4281$; Tag- $1^{-/-}, 50.6 \times$ $\left.10^{3} \pm 4153\right)$. The classification of RGC axons according to their caliber (Fig. $5 G$ ) showed that the majority of them, including the smallest $(<800 \mathrm{~nm})$ and largest $(>1200 \mathrm{~nm})$, were abnormally distributed in the Tag- $1^{-1-}$ mice. We next examined magnifications of optic nerve ultrathin sections for possible cytoskeletal defects associated to this caliber anomaly. Microtubules and neurofilaments in RGC axons appeared more dispersed in the Tag$1^{-1-}$ mice than in heterozygote controls (Fig. $5 H, I$ ). The counting of microtubules and neurofilaments per axon also indicated a loss of microtubules and, mostly, neurofilaments in the absence of Tag-1 (Fig. 5 J,K). Optic nerve lysates from P0 Tag- $1^{-/-}$and Tag- $1^{+/+}$neonates $(n=10$ nerves of each type) analyzed by Western blot for the expression of cytoskeleton proteins revealed a decrease in the expression of cytoskeletal protein MAP-2 in the Tag- $1^{-/-}$nerve, compared with the controls (supplemental Fig. $1 B, C$, available at www.jneurosci.org as supplemental material). Therefore, Tag-1 ${ }^{-1-}$ RGC axons have structural defects occurring during development and persisting in adults.

\section{Hypomyelination and astroglial phenotype of the Tag-1 ${ }^{-/-}$ optic nerve}

Finally, we investigated whether the altered structure and fasciculation of retinal axons were associated to anomalies of surrounding glial cells in the Tag-1 ${ }^{-1-}$ mice.

TAG-1 being expressed by mature oligodendrocytes, we examined the myelin of RGC axons in the adult optic nerve and found several myelination defects in the absence of Tag-1. RGC axons appeared slightly hypomyelinated in the Tag-1 $1^{-1-}$ mice compared with controls (Fig. $6 A-D$ ). The $g$ ratio of myelinated axons, an indicator of myelin sheath thickness, was increased for all classes of axonal caliber (Fig. 6E). Second, a reduced number of myelin lamellae was found in Tag-1-deficient mice (mean number of myelin lamellas \pm SEM: $\operatorname{Tag}-1^{+/-}, 12.80 \pm 0.53$; Tag $1^{-1-}, 10.19 \pm 0.37 ; p=0.0007$ ) (Fig. $6 F$ ). Third, the density of nodes of Ranvier, assessed by immunolabeling of nodal and paranodal regions with anti-NaV and -Caspr/PND Abs, respectively (Fig. $6 G, H$ ), was increased by $\sim 37 \%$ in Tag- $1^{-1-}$ RGC axons compared with controls (number of nodes/900 $\mu \mathrm{m}^{2} \pm$ SEM: Tag- $1^{+/+}, 34 \pm 1.4$; Tag- $1^{-/-}, 46.5 \pm 2.4$; Student's $t$ test, ${ }^{* * *} p<0.001$; number axons per animal $=20 ; n \geq 3$ animals of each genotype). These myelin defects in Tag- $1^{-1-}$ mice, possibly reflecting a reduction of oligodendrocyte population, we counted the number of Olig2 ${ }^{+}$cells in the optic nerve of adult Tag- $1^{+/-}$ 
and Tag- $1^{-1-}$ mice. A similar number of oligodendrocytes was observed between animal types (mean number of Olig $2^{+}$ cells $/ 10^{-5} \mu \mathrm{m}^{2} \pm$ SEM: Tag- $1^{+/-}, 39 \pm 3$; Tag $1^{-1-}, 42 \pm 3 ; p=0.478 ; n=3$ nerves of each type).

Abnormal features of the astroglial environment were also noted in the nerve at the embryonic stage. On ultrathin sections of E18.5 Tag-1 ${ }^{-1-}$ optic nerve, astroglial cell bodies had a more ramified morphology compared with controls (Fig. 7A,B), and their cytoplasmic extensions were loosely contacting RGC fibers, in contrast with controls (Fig. 7C,D). Immunolabeling of cryosections of Tag$1^{-1-}$ and Tag- $1^{+1-}$ optic nerves with the anti-GFAP Ab showed a $20 \%$ increase in the surface of $\mathrm{GFAP}^{+}$labeling in $\mathrm{Tag}-1^{-1-}$, with thinner and more ramified $\mathrm{GFAP}^{+}$astroglial extensions compared with Tag-1 $1^{+/-}$(Fig. 7E,F, Table 3). This astroglial phenotype was associated with a $20 \%$ increase of nerve caliber (Fig. 7G,H). The number of astroglial cells in the Tag- $1^{-/-}$optic nerve was, however, normal, as shown by the number of cells labeled with anti-Pax2 Ab, a marker of all astroglial cell types (Mi and Barres, 1999) (supplemental Fig. 1D,E, available at www.jneurosci.org as supplemental material).

Astroglial cells do not express TAG-1 in the optic nerve. The phenotype of $\mathrm{Tag}-1^{-1-}$ astroglia might thus result from abnormal axoglial contacts caused by the loss of TAG-1 on RGC axons. We examined whether astrocytes established a preferential contact with a TAG-1 substrate. Dissociated cells from E17.5-E18.5 optic nerve were seeded on stripes alternatively coated with laminin alone, or with TAG-1. After 2 DIV, astrocytes and oligodendrocytes were distinguished by immunolabeling with anti-GFAP $\mathrm{Ab}$ (Fig. 8A) and A2B5 Ab (data not shown), respectively. Approximately, $75 \%$ of $\mathrm{GFAP}^{+}$cell bodies were on, or in contact with, TAG-1-coated substrate, whereas A2B5 ${ }^{+}$oligodendrocyte precursors were mostly observed on laminin-coated stripes, and avoided the TAG-1-coated substrate (Fig. 8 B). Optic nerve astroglial cells, but not oligodendrocyte precursors, therefore, have a strong adhesion affinity for TAG-1. It is worth noting that a specific astroglial affinity was also observed for L1, using the same in vitro assay on L1-coated stripes (data not shown).

Finally, to determine whether TAG-1 controls the morphology of astroglial cells, we treated optic nerve astrocytes with soluble human TAG-1 protein and observed the shape of their cell body and their cytoplasmic extensions. E18.5 optic nerve cells were cultured in a medium enhancing their differentiation, alone or with a soluble human TAG-1 $(10 \mathrm{~g} / \mathrm{ml})$. After 2 DIV, immunolabeling with anti-Glast and -GFAP Abs allowed the detection and quantification of radial-astroglial progenitors and astrocytes, respectively. $\mathrm{GFAP}^{+}$cells were classified according to their morphology: precursor-like cells, with a small cell body and a budding cytoplasmic process; early differentiating astrocytes, unipolar or bipolar, with an elongated cell body; astrocytes with multipolar cytoplasmic processes and a large nucleus (Fig. 8C). $\mathrm{GFAP}^{+}$cells represented $\sim 40 \%$ of the cells, independently of culture conditions (Fig. $8 \mathrm{D}$ ). There were predominantly multipolar astrocytes in control cultures, whereas in the presence of TAG-1 the majority of astroglial cells had an elongated morphology (Fig. $8 E$ ). Furthermore, Glast ${ }^{+}$cells were detected after TAG-1 treatment, but not in control culture conditions. Together, these results indicate that the morphology of astroglial cells is modulated by TAG-1, and likely by contact with TAG- ${ }^{+}$ RGC axons.

\section{Discussion}

In the present study, we show that the loss of Tag-1 results in multiple structural defects in the optic nerve, a white matter tract in which TAG-1 is expressed by either RGC axons during embryonic life or by oligodendrocytes during postnatal life. In the embryo and neonate, the transient expression of TAG-1 by RGC axons is critical for the development of axons and neighboring astroglia. TAG-1 is required by axons to establish mutual contacts in vitro, to develop a normal cytoskeleton and caliber size in vivo, as well as to correctly project in the LGN. In addition, TAG-1 regulates astroglial morphology by inhibiting excessive extension of GFAP processes between axons. In the adult Tag-1null mice, axonal caliber abnormalities persist and are aggravated by the loss of $20 \%$ of RGC axons. Additional defects of myelination suggest a role of TAG-1, postnatally, in oligodendrocyte physiology, and in the maintenance of myelin.

\section{TAG-1 contributes to RGC axon fasciculation in the optic nerve}

Previous studies have shown that TAG-1 promotes neuronal survival and axonal growth, and controls guidance of spinal cord commissural neurons (Karagogeos, 2003). Our in vivo data indicate a role of TAG-1 in the fasciculation of RGC axons. This effect is in accordance with findings from previous in vitro studies of TAG-1 on PNS axons (Ruegg et al., 1989; Kunz et al., 1998). Homophilic interactions by TAG-1 are required for RGC axons to bind a TAG-1-coated substrate. In vivo, these homophilic interactions can be used to establish trans contacts (Rader et al., 1993; Brümmendorf and Lemmon, 2001) and promote the fasciculation of TAG-1-expressing RGC axons. Our ultrastructural observations of the Tag- $1^{-/-}$embryonic optic nerve, showing a decreased density and a slight lack of compaction of RGC axons, are in agreement with this model. However, the absence of a clear disorganization of axonal fascicles in the Tag-1 $1^{-1-}$ embryonic optic nerve indicates that other molecules partially compensate, in vivo, the absence of TAG-1 to maintain cohesion between axonal fibers.

We also observed that embryonic RGC axons promptly defasciculate when crossing stripes coated with TAG-1, or growing on CHO-TAG-1-expressing cells. This behavior is likely to be attributable to the high concentration of TAG-1 on the substrate, competing with low physiological membrane concentration of TAG-1 on neighboring axon membranes. Therefore, homophilic TAG-1 interactions could regulate the defasciculation of TAG-1expressing axons in a TAG-1-enriched environment.

One member of the CAM family, L1, also plays a role in axonal fasciculation (Stallcup and Beasley, 1985; Lemmon and McLoon, 1986; Weiland et al., 1997). It is required by retinal axons in the tectum, where their pattern is disorganized in the L1-null neonate (Demyanenko and Maness, 2003). We found that L1 can promote RGC fasciculation as efficiently as TAG-1, but apparently not in synergy with TAG-1. Because of their different spatiotemporal patterns of expression, TAG-1 and L1 may nevertheless play complementary roles in the different segments of the RGT. 

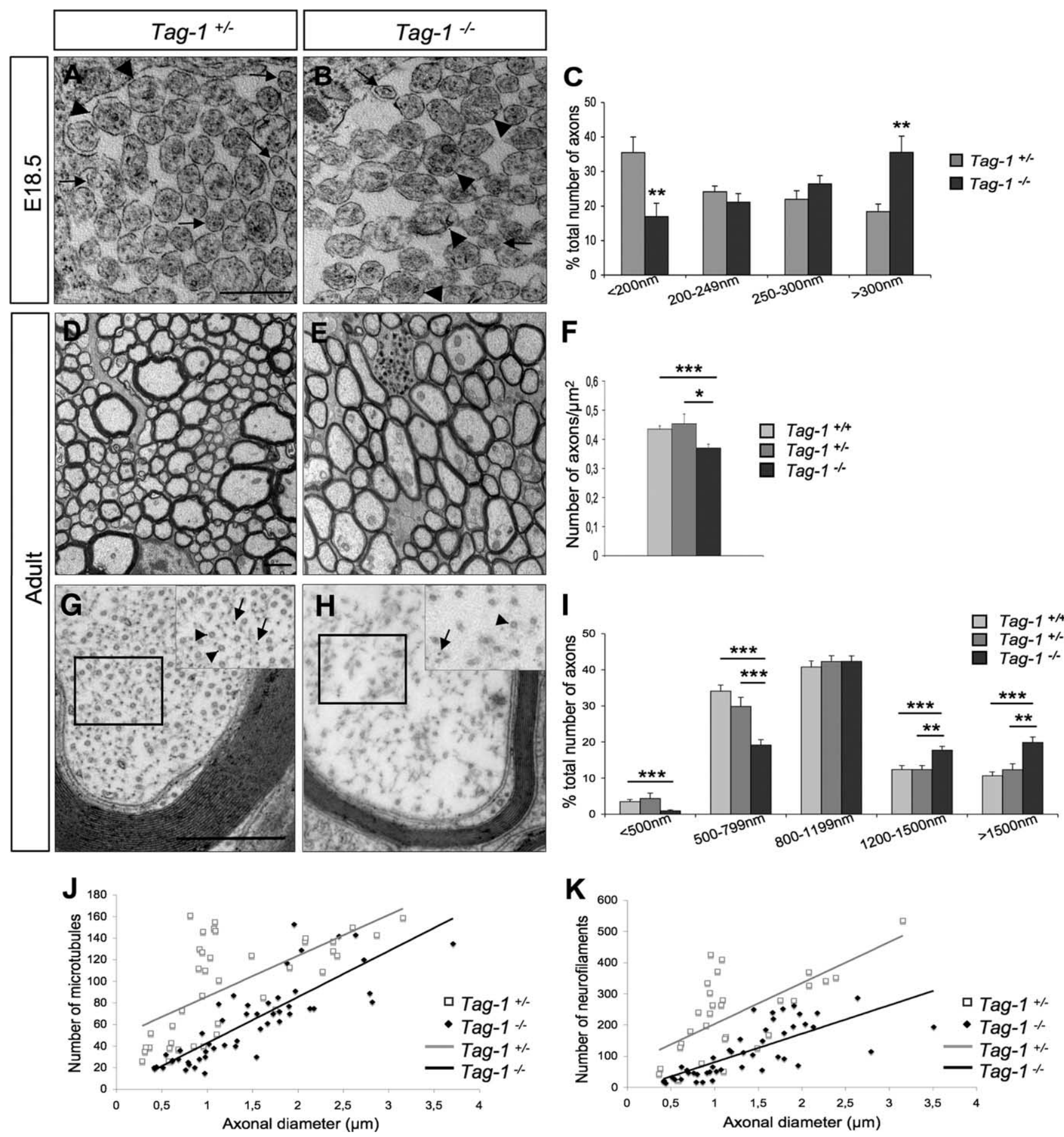

Figure 5. Axonal defects in the embryonic and adult Tag- $1^{-1-}$ optic nerve. A-C, Analysis of ultrathin sections of the optic nerve from E18.5 Tag- $1^{+/-}$and Tag- $1^{-/-}$embryos. Heterozygous mutant embryos ( $\boldsymbol{A}$ ) show more small-caliber axons (arrows) and less large-caliber axons (arrowheads) than homozygotes ( $\boldsymbol{B})$. C, Histogram of the distribution of RGC axons according to their caliber. Tag- $1^{-/-}$axons display a global increase of $\sim 20 \%$ in caliber size [mean axon diameter (in nm): Tag- ${ }^{-1-}, 278 \pm 1 ; \operatorname{Tag}^{-1}{ }^{+/-}, 234 \pm 7$ ]. The pool of small-caliber axons (arrows) is reduced [ $<200 \mathrm{~nm}$ (percentage): Tag- $1^{-1-}, 17 \pm 4 ;$ Tag- $\left.1^{+1-}, 35 \pm 4\right]$, whereas the one of large axons (arrowheads) is increased [ $>300 \mathrm{~nm}$ (percentage): $\left.T a g-1^{-1-}, 35 \pm 5 ; \operatorname{Tag}-1^{+/-}, 18 \pm 2\right] . D-G$, Ultrastructural analysis of the adult optic nerve in $\mathrm{Tag}-1^{-l-}, \mathrm{Tag}_{-1}{ }^{-I+}$, and wild-type mice. Compared with the heterozygotes $(\boldsymbol{D})$, the homozygotes $(\boldsymbol{E})$ have less small-caliber and more large-caliber axons. $\boldsymbol{F}$, Quantification of axonal density in the optic nerve. RGC axons are less numerous in Tag- $~^{-/-}$mice than in controls (number of axons/ $\mu \mathrm{m}^{2}:{\mathrm{Tag}-1^{+/+}}^{+}, 0.435 \pm 0.011 ; \mathrm{Tag}-1^{+/-}, 0.454 \pm 0.033 ; \mathrm{Tag}-1^{-/-}, 0.370 \pm 0.01$ ). G, H, Typical axonal cytoskeletons are shown in electron micrographs of optic nerve axonal cross sections from ${\mathrm{Tag}-1^{+/-}}_{(\boldsymbol{G})}$ and $\mathrm{Tag}-1^{-1-}(\boldsymbol{H})$ mice. Higher magnification pictures in $\boldsymbol{G}$ and $\boldsymbol{H}$ show that the density of both microtubules (arrowheads) and neurofilaments (arrows) is decreased in Tag- $1^{-1-}$ RGC axons, compared with controls. I, Histogram of the relative distribution of RGC axons according to their caliber. No difference is seen between $\mathrm{Tag}-1^{+/+}$and Tag- $1^{+/-}$mice. In the homozygotes, the pool of small-caliber axons $(<800 \mathrm{~nm})$ was reduced by one-half (percentage of axons: Tag- $1^{-/-}, 0.94 \pm 0.23$; Tag- $1^{+/-}, 4.34 \pm 1.5 ;$ Tag- $\left.1^{+1+}, 3.44 \pm 0.55\right)$, whereas the large-caliber axons $\left(\geq 1.2 \mu \mathrm{m}\right.$ ) were in a 50\% excess compared with controls (percentage of axons: Tag- ${ }^{-1-}, 19.87 \pm 1.54 ;$ Tag- $^{-1 /}{ }^{+\prime}$, $\left.12.29 \pm 1.69 ; \mathrm{Tag}-1^{+/+}, 10.65 \pm 1.03\right) . n=3$ animals of each type; $>1000$ axons per each type of animal. $J, \boldsymbol{K}$, Representation of the number of microtubules and neurofilaments according to axonal diameter in the optic nerve of adult Tag- $1^{+/-}$and Tag- $1^{-1-}$ mice. The mean number of microtubules/axon \pm SEM was as follows: $96 \pm 7$ for Tag $-1^{+/-}$and $62 \pm 5$ for Tag- $1^{-1-}$;Student's $t$ test, ${ }^{* * *} p<$ 0.001. The mean number of neurofilaments/axon \pm SEM was as follows: $231 \pm 24$ for Tag- $1^{+/-}$and $113 \pm 12$ for Tag- $1^{-1-}$; Mann-Whitney test, ${ }^{* * *} p<0.001 ; n=3$ animals of each type; $>30$ axons for each type of animal. Scale bars: $\boldsymbol{D}, \boldsymbol{E}, 2 \mu \mathrm{m} ; \boldsymbol{A}, \boldsymbol{B}, 1 \mu \mathrm{m} ; \boldsymbol{H}, \boldsymbol{I}, 0.5 \mu \mathrm{m}$. All data are the mean \pm SEM. Student's $t$ test $(\boldsymbol{C}, \boldsymbol{G})$, Mann-Whitney test $(\boldsymbol{F})\left({ }^{*} p<0.05 ;{ }^{* *} p<0.01 ;{ }^{* * *} p<0.001\right)$. 

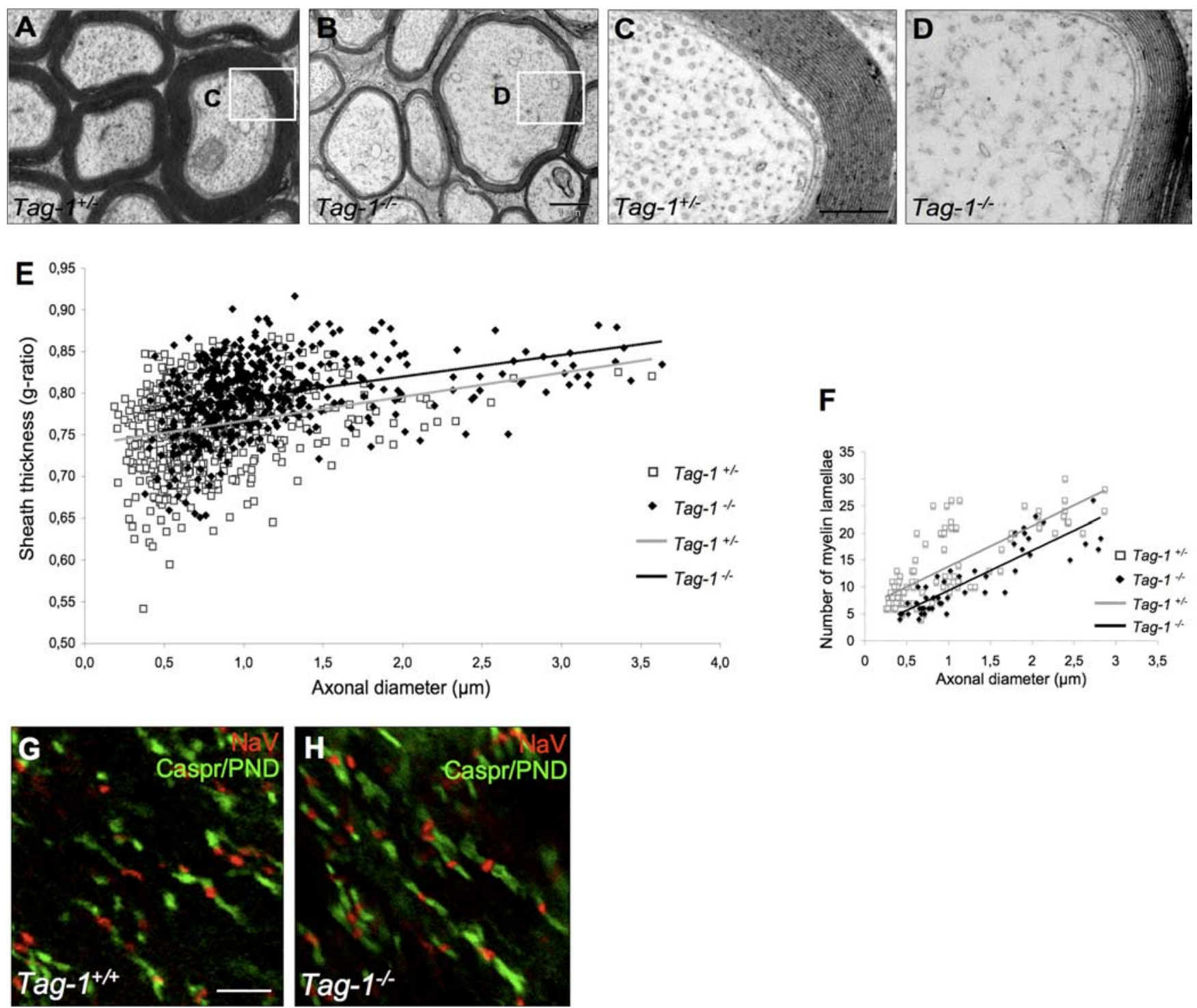

Figure 6. Myelin defects in the Tag- $1^{-/-}$adult optic nerve. $\boldsymbol{A}-\boldsymbol{F}$, Myelin sheath thickness around RGC axons. High magnifications of ultrathin sections of the optic nerve show that the RGC axons display a thinner myelin in Tag-1 homozygote $(\boldsymbol{B}, \boldsymbol{D})$ than in Tag-1 heterozygote $(\boldsymbol{A}, \boldsymbol{C}$ mice. $\boldsymbol{E}$, Representation of the myelin $g$ ratio in function of axonal diameter in the optic nerve of adult Tag- $1^{+/-}$and $\operatorname{Tag}-1^{-1-}$ mice $\left(n=3\right.$ animals of each type; $>100$ axons for each type of animal). Tag- $1^{-1-}$ RGC axons were slightly hypomyelinated $\left(g_{0}=+0.80\right)$ compared with heterozygotes $\left(g_{0}=+0.76\right.$ ). Although less small-caliber axons were observed in homozygotes (black dots) compared with controls (white dots), the $g_{0}$ lines were parallel between homozygotes and controls. The hypomyelination was thus not dependent of axon caliber. $\boldsymbol{F}$, Quantification of the number of myelin lamellae around RGC axons, in function of axonal caliber, in the Tag- $1^{+/-}$and Tag- $1^{-1-}$ mice $\left(n=3\right.$ animals of each type; $>70$ axons for each type of animal). The number of myelin lamellae is lower in Tag- $1^{-1-}$ mice than in controls. $\boldsymbol{G}, \boldsymbol{H}$, The nodes of Ranvier in RGC fibers of adult Tag- $1^{+/+}(\boldsymbol{G})$ and $T a g-1^{-1-}(\boldsymbol{H})$ mice. Horizontal sections of optic nerve double labeled with anti-NaV (red) and -Caspr/PND (green) Abs show an increased number of Na channels in the Tag- $1^{-1-}$ mice. Scale bars: $\mathbf{G}, \boldsymbol{H}, 30 \mu \mathrm{m} ; \boldsymbol{A}, \boldsymbol{B}, 1 \mu \mathrm{m} ; \boldsymbol{C}, \boldsymbol{D}, 250 \mathrm{~nm}$.

TAG-1 modulates the LGN pattern of retinal projections

Distally to the optic nerve, the RGC axons of Tag-1 ${ }^{-1-}$ neonates display $\sim 20 \%$ increased contralateral projection areas in the LGN. In the absence of TAG-1, disruption of molecular interactions between TAG-1 and its partners may lead to errors of RGC axon guidance and projection in the LGN. In the RGT, one possible TAG-1 partner could be Nr-CAM, which binds to TAG-1 (Suter et al., 1995; Rader et al., 1996; Lustig et al., 1999, 2001; Fitzli et al., 2000; Pavlou et al., 2002). Nr-CAM is also expressed in the embryonic chiasm and required by late RGC fibers to establish binocular vision (Williams et al., 2006). TAG-1 and NrCAM may thus physically interact at the chiasm, allowing a proper segregation between ipsilateral and contralateral fibers.
TAG-1 regulates caliber and maturation of cytoskeleton of RGC axons

Embryonic and adult Tag-1-null mutants display abnormal RGC axons. The optic nerve contains almost 50\% less small-caliber axons, whereas the larger caliber axons are increased by $50 \%$. Moreover, the total number of RGC axons in the nerve is reduced by $20 \%$ in adults, suggesting that the developmental defects affect the viability of a subpopulation of RGCs, which are probably eliminated at the postnatal selection stage (Guerin et al., 2006). The morphological phenotype of RGC axons in Tag-1-null mutants is associated with changes in the composition and organization of the axonal cytoskeleton. The microtubule and neurofilament defects occurred already at birth, before (and thus 

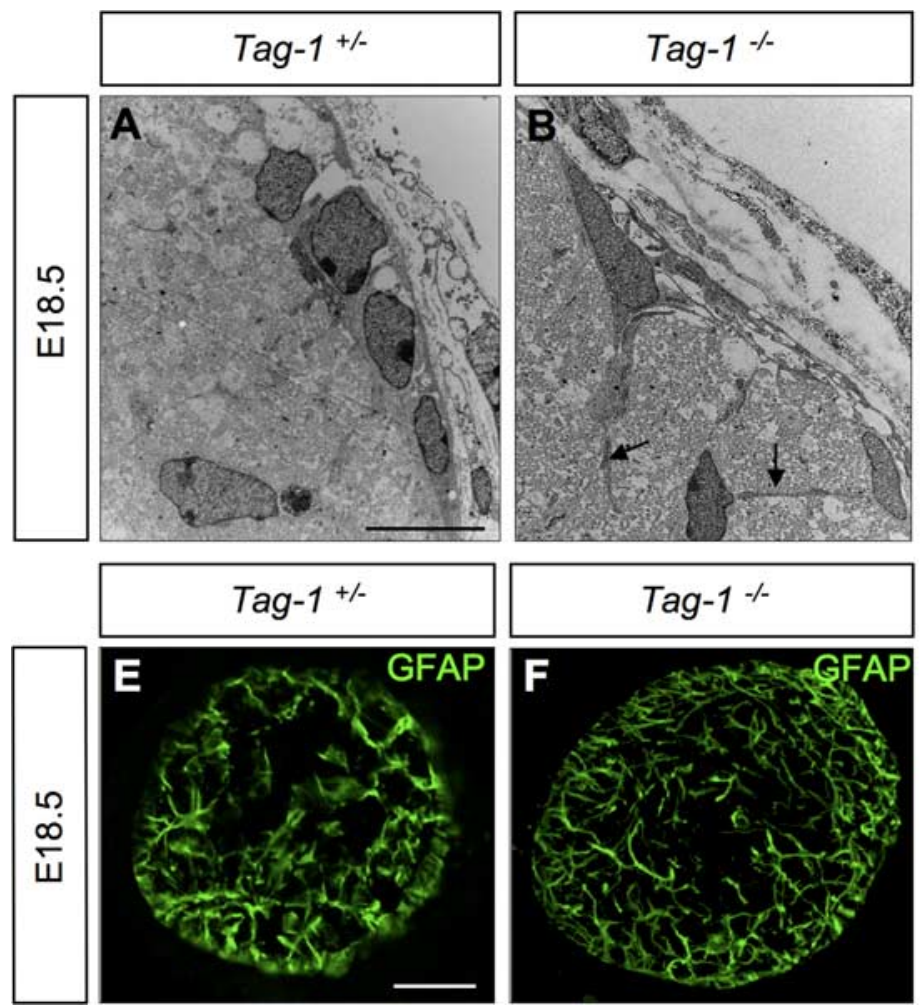
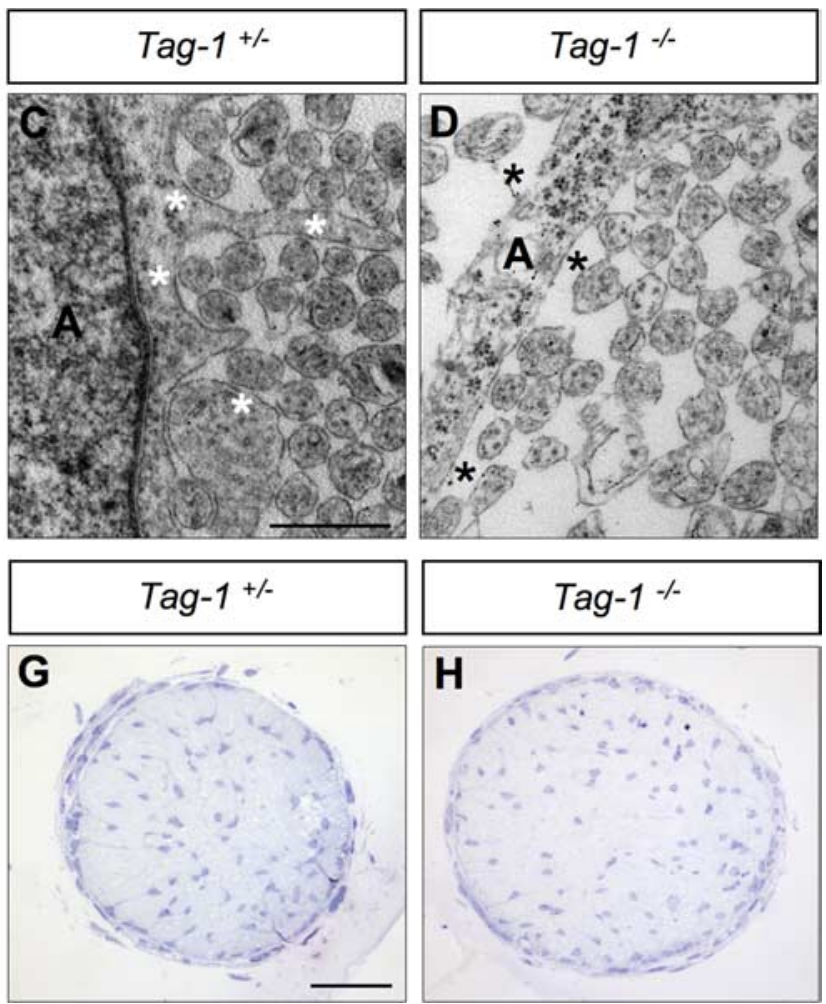

Figure 7. TAG-1 mediates axo-astroglial interactions in the embryonic optic nerve. $\boldsymbol{A}-\boldsymbol{D}$, Ultrathin transversal sections of the optic nerve from E18.5 Tag- $1^{+/-}(\boldsymbol{A}, \boldsymbol{C})$ and Tag- $1^{-/-}(\boldsymbol{B}, \boldsymbol{D})$ mutants observed by electron microscopy. $\boldsymbol{A}, \boldsymbol{B}$, At the periphery of the Tag- $1^{-1-}$ nerve, astrocytes display branched and slender processes ( $\boldsymbol{B}$, black arrows). $\boldsymbol{C}, \boldsymbol{D}$, High magnifications illustrating the axo-astroglial interactions in the optic nerve of Tag- $1^{+/-}(\boldsymbol{C})$ and $\mathrm{Tag}_{-1}^{-1-}(\boldsymbol{D})$ mutants. Axons are often observed at the contact of cytoplasmic extensions of astroglial cells in the control nerves ( $\boldsymbol{C}$, white asterisks), whereas empty spaces frequently occur between axons and astroglial processes in the Tag- $1^{-1-}$ mutants ( $\boldsymbol{D}$, black asterisks). $\boldsymbol{E}, \boldsymbol{F}$, Transverse cryosections of the optic nerve of E18.5 Tag- $1^{+/-}(\boldsymbol{E})$ and $\operatorname{Tag}_{-1}{ }^{-1-}(\boldsymbol{F})$ mutants stained with the anti-GFAP Ab show an expanded astroglial network in the Tag- 1 homozygotes. G, $\boldsymbol{H}$, Semithin transverse sections of the optic nerve of E18.5 heterozygous and homozygous Tag-1 mutants. The caliber of nerve was 10\% larger in homozygous Tag-1 mutants than in controls, without visible signs of edema or fluid infiltration within the tissue. A, Astrocyte. Scale bars: $E-H, 100 \mu \mathrm{m} ; A, B, 10 \mu \mathrm{m} ; C, D, 1 \mu \mathrm{m}$.

Table 3. Surface occupied by GFAP ${ }^{+}$astroglial network in the embryonic optic nerve

\begin{tabular}{llc}
\hline & Optic nerve surface (AU) & GFAP $^{+}$surface (AU) \\
\hline Tag-1 $^{+/-}$ & $254 \times 10^{3} \pm 12 \times 10^{3}$ & $99 \times 10^{3} \pm 5 \times 10^{3}$ \\
Tag-1 $^{-/-}$ & $310 \times 10^{3} \pm 17 \times 10^{3}$ & $120 \times 10^{3} \pm 7 \times 10^{3 *}$ \\
\hline
\end{tabular}

$\mathrm{AU}$, Arbitrary unit. $n=7$ animals of each type. ${ }^{*} p<0.05$, Student's $t$ test. All data are mean \pm SEM.

independently of) myelin formation, which also contributes to the maturation of axonal cytoskeleton (Brady et al., 1999). Two alternative explanations can be proposed for this developmental phenotype of Tag1 ${ }^{-1-}$ RGC axons. First, if axon-to-axon interactions are being reduced in the absence of TAG-1, the surface of each axon is less compressed by its neighbors, and all the RGC axons would increase their caliber in the optic nerve. This should not provoke changes in the composition of cytoskeletal proteins; however, these are found in the Tag-1 ${ }^{-1-}$ RGC axons. Second, the caliber phenotype of RGC axons in Tag1 ${ }^{-1-}$ mice may reflect an abnormal specification of RGCs: subpopulations of RGCs forming small-caliber axons are selectively inhibited, and even eliminated after birth, whereas the development of RGCs with large-caliber axons is promoted. Such a possibility is in accordance with the abnormal cytoskeleton of RGC axons in the Tag$1^{-1-}$ mice and supported by the expression of Tag-1 during the period of RGC specification in the retina; as well as by reports on the role of contactins in the Notch and APP (amyloid precursor protein) signaling pathways at early stages of neural progenitor development (Austin et al., 1995; Ma et al., 2008).

\section{Axonal TAG-1 modulates astroglial morphology}

In the Tag-1-null embryo, the tissue organization of the optic nerve is also disrupted at the level of astroglia. Immunolabeling of the $\mathrm{GFAP}^{+}$cytoskeleton and ultrastructural examination of astroglial cells show an expanded and more ramified astroglial network in the nerve of Tag-1 ${ }^{-1-}$ embryos compared with controls. Astroglial cells, which do not express TAG-1, thus require to either physically contact TAG- ${ }^{+}$RGC axons, or bind a soluble TAG-1 secreted by axons. The receptor system mediating TAG-1 effect on astrocytes remains to be identified, but might include RPTP (receptor protein tyrosine phosphatase) family members already reported to bind TAG-1 and contribute to astroglial development (Zeng et al., 1999; Parent et al., 2007). Although we cannot exclude that the astroglial phenotype of Tag-1 ${ }^{-1-}$ embryonic optic nerve simply corresponds to a type of astrogliosis as a consequence of RGC axon defects, it suggests that RGC axons temporally regulate astroglial expansion, thus preserving space for their own growth. This is in agreement with the disappearance of TAG-1 from the surface of RGC axons around birth, when all RGC axons have developed, and just before astroglial processes ramify extensively between and within axonal fascicles (Liu and Neufeld, 2004). Interestingly, it is also in accordance with the observations that downregulation of Tag-1 expression and repression of astroglial maturation are both controlled by thyroid hormones, which are upregulated at birth (AlvarezDolado et al., 2001; Manzano et al., 2007). 

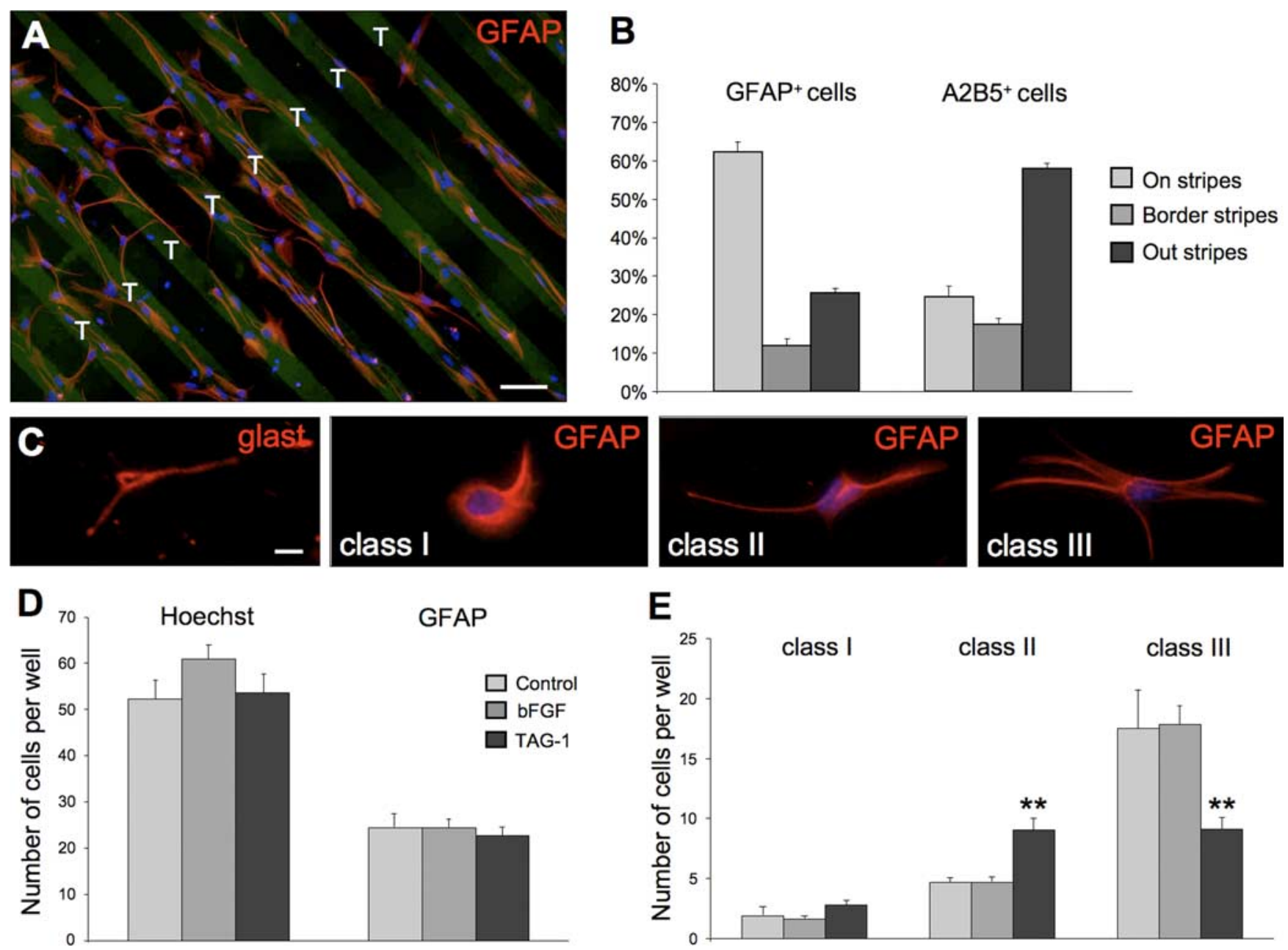

E

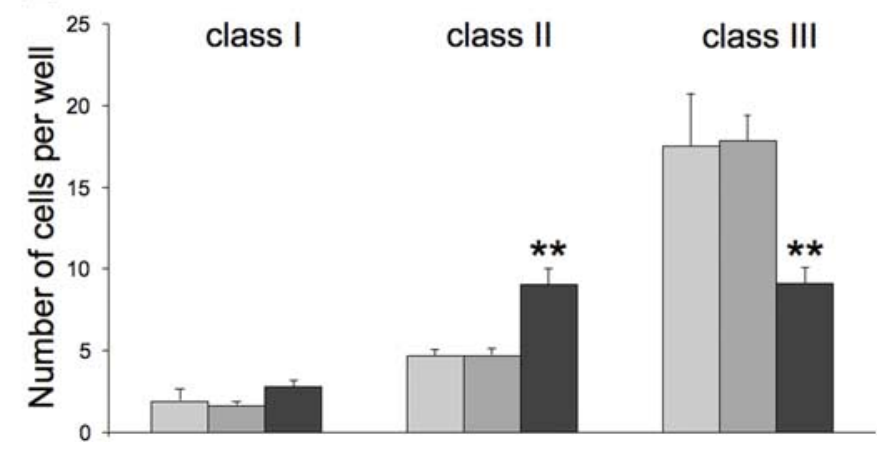

Figure 8. Morphological responses of astroglial cells to TAG-1 in vitro. $A, B$, Stripe assay performed on cells dissociated from E18.5 optic nerves and cultured in contact with stripes coated with laminin alone, or with TAG-1 (T). $A$, Astrocytes immunolabeled with anti-GFAP Ab (red) show a preferent adhesion on the TAG-1 substrate. $\boldsymbol{B}$, Histogram represents the percentage of optic nerve cells observed on, out, or at the border of, TAG-1-coated stripes ( $n=3$ independent series of experiments). Approximately $75 \%$ of GFAP ${ }^{+}$cells were in contact or at the border of TAG-1-coated stripes. In the same experiments, oligodendrocyte precursors immunolabeled with the A2B5 Ab behave differently than astrocytes, avoiding the contact with TAG-1. C-E, Effect of TAG-1 on the morphology of astroglial cells. Dissociated cells from E17.5 optic nerves were cultured in control medium alone, supplemented with bFGF, or with bFGF and soluble human TAG-1 (10 mg/ml), to promote astrocyte differentiation. C, The radial/astroglial cells detected were as follows: radial/astroglial progenitors immunolabeled with anti-Glast Ab; GFAP ${ }^{+}$precursor-like astroglial cells bearing one short cytoplasmic process (class I astrocytes); early differentiating GFAP ${ }^{+}$astroglial cells with a unipolar or bipolar shape of (class II astrocytes); GFAP ${ }^{+}$ramified astrocytes (class III astrocytes). $\boldsymbol{D}$, Counting of the average numbers of cells ( Hoechst ${ }^{+}$) and astroglial cells (GFAP ${ }^{+}$) in each culture condition. TAG-1 did not induce changes in the number and proportion of astroglial cells in culture. E, Histogram represents the proportion of each class of astroglial cells (classes I-III) in each culture condition. The control medium alone, or supplemented with bFGF, favors the morphological differentiation of ramified astrocytes (class III). In contrast, TAG-1 promotes the maintenance of elongated astroglial cells (class II) at the expense of ramified astrocytes (alternate Welch's $t$ test; class $\mathrm{I}, p_{\mathrm{bFGF} / \mathrm{TAG}-1}=0.006, p_{\mathrm{ctr} / \mathrm{TAG}-1}=0.0324$; class II, $p_{\mathrm{bFGF} / \mathrm{TAG}-1}=0.0002, p_{\mathrm{ctr} / \mathrm{TAG}-1}=0.0003$; class III, $\left.p_{\mathrm{bFGF} / \mathrm{TAG}-1}<0.0001, p_{\mathrm{ctr} / \mathrm{TAG}}=0.0182\right)$. T, TAG-1. Error bars indicate SEM. Scale bars: $A, 100$ $\mu \mathrm{m} ; \mathrm{C}, 10 \mu \mathrm{m} .{ }^{* *} p<0.01$.

\section{Oligodendroglial effect of TAG-1 on myelination}

TAG-1 is expressed by RGC axons when oligodendrocyte precursor cells (OPCs) enter the optic nerve. However, TAG-1 does not promote, in vitro, the survival and adhesion of OPCs, and, in vivo, the number and pattern of distribution of OPCs in the optic nerve appear normal in embryonic Tag-1 ${ }^{-1-}$ mutants. In contrast, postnatal myelinating oligodendrocytes express Tag-1 and the RGC axons of adult Tag-1-null mutants display myelin defects. In the Tag- $1^{-1-}$ mice, the RGC axons show, independently of their caliber, a thinner myelin sheath with a reduced number of myelin wraps, suggesting that the production and/or maintenance of myelin by TAG-1-deficient oligodendrocytes is impaired. Hypomyelination had not been reported in a previous study of Tag- $1^{-1-}$ ventral spinal cord (Traka et al., 2003). Region-specific cues may account for the phenotype difference between the optic nerve and the spinal cord. However, it is worth noting that the hypomyelination in Tag- $1^{-1-}$ optic nerve is subtle and that its unambiguous detection required a quantitative approach not performed in the previous study. In addition to the reduced concentration of $\mathrm{K}^{+}$channels in the Tag-1 ${ }^{-1-}$ optic nerve reported by Traka et al. (2003), the present analysis shows nodal abnormalities, because the number of nodes, revealed by $\mathrm{Na}^{+}$channel labeling, is increased in Tag- $1^{-1-}$ mice. TAG-1 has therefore a critical role both in the organization of juxtaparanodal regions and the control of internodal length. Additional studies will be required to establish whether this latter anomaly is linked to the developmental cytoskeletal defects induced by TAG-1 loss on the axonal membrane.

Together, our study reveals multiple and subtle roles played by TAG-1 during the growth, navigation, and myelination of RGC axons. Among the numerous CAMs expressed in the RGT (Osterfield et al., 2008), TAG-1 displays specific functions, maintain- 
ing the structural cohesion between axons and contributing to the refinement and diversification of the response of subpopulations of axons to environmental cues. The analysis of compound CAM mutants should shed light on the combinatorial functions of CAMs required for white matter tract development.

\section{References}

Alvarez-Dolado M, Figueroa A, Kozlov S, Sonderegger P, Furley AJ, Muñoz A (2001) Thyroid hormone regulates TAG-1 expression in the developing rat brain. Eur J Neurosci 14:1209-1218.

Austin CP, Feldman DE, Ida JA Jr, Cepko CL (1995) Vertebrate retinal ganglion cells are selected from competent progenitors by the action of Notch. Development 121:3637-3650.

Bartsch U, Kirchhoff F, Schachner M (1989) Immunohistological localization of the adhesion molecules L1, N-CAM, and MAG in the developing and adult optic nerve of mice. J Comp Neurol 284:451-462.

Brady ST, Witt AS, Kirkpatrick LL, de Waegh SM, Readhead C, Tu PH, Lee VM (1999) Formation of compact myelin is required for maturation of the axonal cytoskeleton. J Neurosci 19:7278-7288.

Brümmendorf T, Lemmon V (2001) Immunoglobulin superfamily receptors: cis-interactions, intracellular adapters and alternative splicing regulate adhesion. Curr Opin Cell Biol 13:611-618.

Castellani V, De Angelis E, Kenwrick S, Rougon G (2002) Cis and trans interactions of L1 with neuropilin-1 control axonal responses to semaphorin 3A. EMBO J 21:6348-6357.

Charles P, Hernandez MP, Stankoff B, Aigrot MS, Colin C, Rougon G, Zalc B, Lubetzki C (2000) Negative regulation of central nervous system myelination by polysialylated-neural cell adhesion molecule. Proc Natl Acad Sci U S A 97:7585-7590.

Colello RJ, Guillery RW (1990) The early development of retinal ganglion cells with uncrossed axons in the mouse: retinal position and axonal course. Development 108:515-523.

Demerens C, Stankoff B, Logak M, Anglade P, Allinquant B, Couraud F, Zalc B, Lubetzki C (1996) Induction of myelination in the central nervous system by electrical activity. Proc Natl Acad Sci U S A 93:9887-9892.

Demyanenko GP, Maness PF (2003) The L1 cell adhesion molecule is essential for topographic mapping of retinal axons. J Neurosci 23:530-538.

Dodd J, Morton SB, Karagogeos D, Yamamoto M, Jessell TM (1988) Spatial regulation of axonal glycoprotein expression on subsets of embryonic spinal neurons. Neuron 1:105-116.

Dräger UC (1985) Birth dates of retinal ganglion cells giving rise to the crossed and uncrossed optic projections in the mouse. Proc R Soc Lond B Biol Sci 224:57-77.

Felsenfeld DP, Hynes MA, Skoler KM, Furley AJ, Jessell TM (1994) TAG-1 can mediate homophilic binding, but neurite outgrowth on TAG-1 requires an L1-like molecule and beta 1 integrins. Neuron 12:675-690.

Fitzli D, Stoeckli ET, Kunz S, Siribour K, Rader C, Kunz B, Kozlov SV, Buchstaller A, Lane RP, Suter DM, Dreyer WJ, Sonderegger P (2000) A direct interaction of axonin- 1 with $\mathrm{NgCAM}$-related cell adhesion molecule $(\mathrm{Nr}-$ CAM) results in guidance, but not growth of commissural axons. J Cell Biol 149:951-968.

Fukamauchi F, Aihara O, Wang YJ, Akasaka K, Takeda Y, Horie M, Kawano H, Sudo K, Asano M, Watanabe K, Iwakura Y (2001) TAG-1-deficient mice have marked elevation of adenosine A1 receptors in the hippocampus. Biochem Biophys Res Commun 281:220-226.

Furley AJ, Morton SB, Manalo D, Karagogeos D, Dodd J, Jessell TM (1990) The axonal glycoprotein TAG-1 is an immunoglobulin superfamily member with neurite outgrowth-promoting activity. Cell 61:157-170.

Guerin MB, McKernan DP, O'Brien CJ, Cotter TG (2006) Retinal ganglion cells: dying to survive. Int J Dev Biol 50:665-674.

Karagogeos D (2003) Neural GPI-anchored cell adhesion molecules. Front Biosci 8:1304-1320.

Kozlov SV, Giger RJ, Hasler T, Korvatska E, Schorderet DF, Sonderegger P (1995) The human TAX1 gene encoding the axon-associated cell adhesion molecule TAG-1/axonin-1: genomic structure and basic promoter. Genomics 30:141-148.

Kuhn TB, Stoeckli ET, Condrau MA, Rathjen FG, Sonderegger P (1991) Neurite outgrowth on immobilized axonin-1 is mediated by a heterophilic interaction with L1 (G4). J Cell Biol 115:1113-1126.

Kunz B, Lierheimer R, Rader C, Spirig M, Ziegler U, Sonderegger P (2002) Axonin-1/TAG-1 mediates cell-cell adhesion by a cis-assisted transinteraction. J Biol Chem 277:4551-4557.
Kunz S, Spirig M, Ginsburg C, Buchstaller A, Berger P, Lanz R, Rader C, Vogt L, Kunz B, Sonderegger P (1998) Neurite fasciculation mediated by complexes of axonin-1 and $\mathrm{Ng}$ cell adhesion molecule. J Cell Biol 143:1673-1690.

Lagenaur C, Lemmon V (1987) An L1-like molecule, the 8D9 antigen, is a potent substrate for neurite extension. Proc Natl Acad Sci U S A 84:7753-7757.

Lang DM, Warren JT Jr, Klisa C, Stuermer CA (2001) Topographic restriction of TAG-1 expression in the developing retinotectal pathway and target dependent reexpression during axon regeneration. Mol Cell Neurosci 17:398-414.

Laub F, Lei L, Sumiyoshi H, Kajimura D, Dragomir C, Smaldone S, Puche AC, Petros TJ, Mason C, Parada LF, Ramirez F (2005) Transcription factor KLF7 is important for neuronal morphogenesis in selected regions of the nervous system. Mol Cell Biol 25:5699-5711.

Lemmon V, McLoon SC (1986) The appearance of an L1-like molecule in the chick primary visual pathway. J Neurosci 6:2987-2994.

Lemmon V, Farr KL, Lagenaur C (1989) L1-mediated axon outgrowth occurs via a homophilic binding mechanism. Neuron 2:1597-1603.

Liu B, Neufeld AH (2004) Activation of epidermal growth factor receptors directs astrocytes to organize in a network surrounding axons in the developing rat optic nerve. Dev Biol 102:16690-16695.

Lustig M, Sakurai T, Grumet M (1999) Nr-CAM promotes neurite outgrowth from peripheral ganglia by a mechanism involving axonin- 1 as a neuronal receptor. Dev Biol 209:340-351.

Lustig M, Erskine L, Mason CA, Grumet M, Sakurai T (2001) Nr-CAM expression in the developing mouse nervous system: ventral midline structures, specific fiber tracts, and neuropilar regions. J Comp Neurol 434:13-28.

Ma QH, Futagawa T, Yang WL, Jiang XD, Zeng L, Takeda Y, Xu RX, Bagnard D, Schachner M, Furley AJ, Karagogeos D, Watanabe K, Dawe GS, Xiao ZC (2008) A TAG1-APP signalling pathway through Fe65 negatively modulates neurogenesis. Nat Cell Biol 10:283-294.

Malhotra JD, Tsiotra P, Karagogeos D, Hortsch M (1998) Cis-activation of L1-mediated ankyrin recruitment by TAG-1 homophilic cell adhesion. J Biol Chem 273:33354-33359.

Mann F, Harris WA, Holt CE (2004) New views on retinal axon development: a navigation guide. Int J Dev Biol 48:957-964.

Manzano J, Bernal J, Morte B (2007) Influence of thyroid hormones on maturation of rat cerebellar astrocytes. Int J Dev Neurosci 25:171-179.

McEvilly RJ, Erkman L, Luo L, Sawchenko PE, Ryan AF, Rosenfeld MG (1996) Requirement for Brn-3.0 in differentiation and survival of sensory and motor neurons. Nature 384:574-577.

Menegoz M, Gaspar P, Le Bert M, Galvez T, Burgaya F, Palfrey C, Ezan P, Arnos F, Girault JA (1997) Paranodin, a glycoprotein of neuronal paranodal membranes. Neuron 19:319-331.

Mi H, Barres BA (1999) Purification and characterization of astrocyte precursor cells in the developing rat optic nerve. J Neurosci 19:1049-1061.

Milev P, Maurel P, Häring M, Margolis RK, Margolis RU (1996) TAG-1/ axonin-1 is a high-affinity ligand of neurocan, phosphacan/proteintyrosine phosphatase-zeta/beta, and N-CAM. J Biol Chem 271:15716-15723.

Morino P, Buchstaller A, Giger R, Sonderegger P, Rager G (1996) Differential expression of the mRNAs of the axonal glycoproteins axonin-1 and $\mathrm{NgCAM}$ in the developing chick retina. Brain Res Dev Brain Res 91:252-259.

Ono K, Yasui Y, Rutishauser U, Miller RH (1997) Focal ventricular origin and migration of oligodendrocyte precursors into the chick optic nerve. Neuron 19:283-292.

Oster SF, Deiner M, Birgbauer E, Sretavan DW (2004) Ganglion cell axon pathfinding in the retina and optic nerve. Semin Cell Dev Biol 15:125-136.

Osterfield M, Egelund R, Young LM, Flanagan JG (2008) Interaction of amyloid precursor protein with contactins and $\mathrm{NgCAM}$ in the retinotectal system. Development 135:1189-1199.

Parent AS, Mungenast AE, Lomniczi A, Sandau US, Peles E, Bosch MA, Rønnekleiv OK, Ojeda SR (2007) A contactin-receptor-like protein tyrosine phosphatase beta complex mediates adhesive communication between astroglial cells and gonadotrophin-releasing hormone neurones. J Neuroendocrinol 19:847-859.

Pavlou O, Theodorakis K, Falk J, Kutsche M, Schachner M, Faivre-Sarrailh C, Karagogeos D (2002) Analysis of interactions of the adhesion molecule 
TAG-1 and its domains with other immunoglobulin superfamily members. Mol Cell Neurosci 20:367-381.

Prestoz L, Chatzopoulou E, Lemkine G, Spassky N, LeBras B, Kagawa T, Ikenaka K, Zalc B, Thomas J-L (2004) Control of axonophilic, migration of oligodendrocyte precursor cells by Eph/ephrin interaction. Neuron Glia Biol 1:73-83.

Rader C, Stoeckli ET, Ziegler U, Osterwalder T, Kunz B, Sonderegger P (1993) Cell-cell adhesion by homophilic interaction of the neuronal recognition molecule axonin-1. Eur J Biochem 215:133-141.

Rader C, Kunz B, Lierheimer R, Giger RJ, Berger P, Tittmann P, Gross H, Sonderegger P (1996) Implications for the domain arrangement of axonin-1 derived from the mapping of its NgCAM binding site. EMBO J 15:2056-2068.

Rager G, Morino P, Schnitzer J, Sonderegger P (1996) Expression of the axonal cell adhesion molecules axonin-1 and Ng-CAM during the development of the chick retinotectal system. J Comp Neurol 365:594-609.

Rathjen FG, Wolff JM, Frank R, Bonhoeffer F, Rutishauser U (1987) Membrane glycoproteins involved in neurite fasciculation. J Cell Biol 104:343-353.

Ravary A, Muzerelle A, Hervé D, Pascoli V, Ba-Charvet KN, Girault JA, Welker E, Gaspar P (2003) Adenylate cyclase 1 as a key actor in the refinement of retinal projection maps. J Neurosci 23:2228-2238.

Ruegg MA, Stoeckli ET, Lanz RB, Streit P, Sonderegger P (1989) A homologue of the axonally secreted protein axonin-1 is an integral membrane protein of nerve fiber tracts involved in neurite fasciculation. J Cell Biol 109:2363-2378.

Schachner M (1991) Cell surface recognition and neuron-glia interactions. Ann N Y Acad Sci 633:105-112.

Small RK, Riddle P, Noble M (1987) Evidence for migration of oligodendrocyte-type-2 astrocyte progenitor cells into the developing rat optic nerve. Nature 328:155-157.

Spassky N, de Castro F, Le Bras B, Heydon K, Quéraud-LeSaux F, BlochGallego E, Chédotal A, Zalc B, Thomas JL (2002) Directional guidance of oligodendroglial migration by class 3 semaphorins and netrin-1. J Neurosci 22:5992-6004.

Stallcup WB, Beasley L (1985) Involvement of the nerve growth factor inducible large external glycoprotein (NILE) in neurite fasciculation in primary cultures of rat brain. Proc Natl Acad Sci U S A 82:1276-1280.

Stoeckli ET, Landmesser LT (1995) Axonin-1, Nr-CAM, and Ng-CAM play different roles in the in vivo guidance of chick commissural neurons. Neuron 14:1165-1179.

Stoeckli ET, Kuhn TB, Duc CO, Ruegg MA, Sonderegger P (1991) The ax- onally secreted protein axonin- 1 is a potent substratum for neurite growth. J Cell Biol 112:449-455.

Stoeckli ET, Sonderegger P, Pollerberg GE, Landmesser LT (1997) Interference with axonin-1 and NrCAM interactions unmasks a floor-plate activity inhibitory for commissural axons. Neuron 18:209-221.

Suter DM, Pollerberg GE, Buchstaller A, Giger RJ, Dreyer WJ, Sonderegger P (1995) Binding between the neural cell adhesion molecules axonin-1 and $\mathrm{Nr}-\mathrm{CAM} /$ Bravo is involved in neuron-glia interaction. J Cell Biol 131:1067-1081.

Traka M, Dupree JL, Popko B, Karagogeos D (2002) The neuronal adhesion protein TAG-1 is expressed by Schwann cells and oligodendrocytes and is localized to the juxtaparanodal region of myelinated fibers. J Neurosci 22:3016-3024.

Traka M, Goutebroze L, Denisenko N, Bessa M, Nifli A, Havaki S, Iwakura Y, Fukamauchi F, Watanabe K, Soliven B, Girault JA, Karagogeos D (2003) Association of TAG-1 with Caspr2 is essential for the molecular organization of juxtaparanodal regions of myelinated fibers. J Cell Biol 162:1161-1172.

Tsiotra PC, Theodorakis K, Papamatheakis J, Karagogeos D (1996) The fibronectin domains of the neural adhesion molecule TAX-1 are necessary and sufficient for homophilic binding. J Biol Chem 271:29216-29222.

Van Vactor D (1998) Adhesion and signaling in axonal fasciculation. Curr Opin Neurobiol 8:80-86.

von Boxberg Y, Deiss S, Schwarz U (1993) Guidance and topographic stabilization of nasal chick retinal axons on target-derived components in vitro. Neuron 10:345-357.

Weiland UM, Ott H, Bastmeyer M, Schaden H, Giordano S, Stuermer CA (1997) Expression of an L1-related cell adhesion molecule on developing CNS fiber tracts in zebrafish and its functional contribution to axon fasciculation. Mol Cell Neurosci 9:77-89.

Williams SE, Grumet M, Colman DR, Henkemeyer M, Mason CA, Sakurai T (2006) A role for Nr-CAM in the patterning of binocular visual pathways. Neuron 50:535-547.

Wolfer DP, Henehan-Beatty A, Stoeckli ET, Sonderegger P, Lipp HP (1994) Distribution of TAG-1/axonin-1 in fiber tracts and migratory streams of the developing mouse nervous system. J Comp Neurol 345:1-32.

Zelina P, Avci HX, Thelen K, Pollerberg GE (2005) The cell adhesion molecule NrCAM is crucial for growth cone behaviour and pathfinding of retinal ganglion cell axons. Development 132:3609-3618.

Zeng L, D’Alessandri L, Kalousek MB, Vaughan L, Pallen CJ (1999) Protein tyrosine phosphatase alpha (PTPalpha) and contactin form a novel neuronal receptor complex linked to the intracellular tyrosine kinase fyn. J Cell Biol 147:707-714. 